University of Nebraska - Lincoln

DigitalCommons@University of Nebraska - Lincoln

2000

\title{
The effect of biogenic Fe(II) on the stability and sorption of Co(II)EDTA22 to goethite and a subsurface sediment
}

John M. Zachara

Pacific Northwest National Laboratory, john.zachara@pnl.gov

Steven Smith

Pacific Northwest National Laboratory, steven.smith@pnl.gov

James K. Fredrickson

Pacific Northwest National Laboratory, jim.fredrickson@pnl.gov

Follow this and additional works at: https://digitalcommons.unl.edu/usdoepub

Part of the Bioresource and Agricultural Engineering Commons

Zachara, John M.; Smith, Steven; and Fredrickson, James K., "The effect of biogenic Fe(II) on the stability and sorption of Co(II)EDTA22 to goethite and a subsurface sediment" (2000). US Department of Energy Publications. 248.

https://digitalcommons.unl.edu/usdoepub/248

This Article is brought to you for free and open access by the U.S. Department of Energy at DigitalCommons@University of Nebraska - Lincoln. It has been accepted for inclusion in US Department of Energy Publications by an authorized administrator of DigitalCommons@University of Nebraska - Lincoln. 


\title{
PII S0016-7037(99)00427-5
}

\section{The effect of biogenic $\mathrm{Fe}$ (II) on the stability and sorption of Co(II)EDTA ${ }^{2-}$ to goethite and a subsurface sediment}

\author{
John M. Zachara,* Steven C. Smith, and James K. Fredrickson \\ ${ }^{1}$ Pacific Northwest National Laboratory, Richland, Washington 99352 USA
}

(Received May 4, 1999; accepted in revised form December 1, 1999)

\begin{abstract}
Laboratory experiments were conducted with suspensions of goethite $(\alpha$-FeOOH) and a subsurface sediment to assess the influence of bacterial iron reduction on the fate of Co(II)EDTA ${ }^{2-}$, a representative metal-ligand complex of intermediate stability $\left(\log \mathrm{K}_{\mathrm{Co} \text { (II)EDTA }}=17.97\right)$. The goethite was synthetic $(\mathrm{ca} .55$ $\mathrm{m}^{2} / \mathrm{g}$ ) and the sediment was a Pleistocene age, Fe(III) oxide-containing material from the Atlantic coastal plain (Milford). Shewanella alga strain BrY, a dissimilatory iron reducing bacterium (DIRB), was used to promote $\mathrm{Fe}(\mathrm{III})$ oxide reduction. Sorption isotherms and $\mathrm{pH}$ adsorption edges were measured for $\mathrm{Co}^{2+}, \mathrm{Fe}^{2+}$, $\mathrm{Co}(\mathrm{II}) \mathrm{EDTA}^{2-}$, and $\mathrm{Fe}(\mathrm{II}) \mathrm{EDTA}^{2-}$ on the two sorbents in $0.001 \mathrm{~mol} / \mathrm{L} \mathrm{Ca}\left(\mathrm{ClO}_{4}\right)_{2}$ to aid in experiment interpretation. Anoxic suspensions of the sorbents in PIPES buffer at $\mathrm{pH}$ 6.5-7.0 were spiked with Co(II)EDTA ${ }^{2-}\left(10^{-5} \mathrm{~mol} / \mathrm{L},{ }^{60} \mathrm{Co}\right.$ and ${ }^{14} \mathrm{EDTA}$ labeled $)$, inoculated with $\mathrm{BrY}\left(1-6 \times 10^{8}\right.$ organisms $\left./ \mathrm{mL}\right)$, and the headspace filled with a $\mathrm{N}_{2} / \mathrm{H}_{2}$ gas mix. The experiments were conducted under non-growth conditions. The medium did not contain $\mathrm{PO}_{4}^{3-}$ (with one exception), trace elements, or vitamins. The tubes were incubated under anoxic conditions at $25^{\circ} \mathrm{C}$ for time periods in excess of $100 \mathrm{~d}$. Replicate tubes were sacrificed and analyzed at desired time periods for $\mathrm{pH}, \mathrm{Fe}(\mathrm{II})_{\mathrm{TOT}}, \mathrm{Fe}_{(\mathrm{aq})}^{2+},{ }^{60} \mathrm{Co}$, and ${ }^{14} \mathrm{EDTA}$. Abiotic analogue experiments

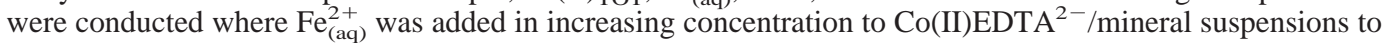
simulate the influence of bacterial Fe(II) evolution. The DIRB generated Fe(II) from both goethite and the Milford sediment that was strongly sorbed by mineral surfaces. Aqueous $\mathrm{Fe}^{2+}$ increased during the experiment as surfaces became saturated; $\mathrm{Fe}_{(\mathrm{aq})}^{2+}$ induced the dissociation of $\mathrm{Co}$ (II)EDTA ${ }^{2-}$ into a mixture of $\mathrm{Co}^{2+}$, $\mathrm{Co}(\mathrm{II}) \mathrm{EDTA}^{2-}$, and Fe(II)EDTA ${ }^{2-}\left(\log \mathrm{K}_{\mathrm{Fe}(\mathrm{II}) \mathrm{EDTA}}=15.98\right)$. The extent of dissociation of Co(II)EDTA ${ }^{2-}$ was greater in the subsurface sediment because it sorbed Fe(II) less strongly than did goethite. The post dissociation sorption behavior of $\mathrm{Co}^{2+}$ was dependent on $\mathrm{pH}$ and the intrinsic sorptivity of the solid phases. Dissociation generally lead to an increase in the sorption (e.g., $\mathrm{K}_{\mathrm{d}}$ ) of $\mathrm{Co}^{2+}$ relative to $\mathrm{EDTA}^{4-}$ (form unspecified). Sorbed biogenic $\mathrm{Fe}(\mathrm{II})$ competed with free $\mathrm{Co}_{(\mathrm{ag})}^{2+}$ and reduced its sorption relative to unreduced material. It is concluded that cationic radionuclides such as ${ }^{60} \mathrm{Co}$ or ${ }^{239 / 240} \mathrm{Pu}$, which may be mobilized from disposed wastes by complexation with $\mathrm{EDTA}^{4-}$, may become immobilized in groundwater zones where dissimilatory bacterial iron reduction is operative. Copyright $($ C 2000 Elsevier Science Ltd
\end{abstract}

\section{INTRODUCTION}

Organic ligand complexation can modify the aqueous geochemical behavior of metal ions by either increasing or decreasing the tendency of the metal ion to associate with particle surfaces. Complexing ligands such as ethylenediaminetetraacetic acid $\left(\right.$ EDTA $\left.^{4-}\right)$ decrease metal ion sorption in circumneutral waters by suppressing surface coordination reactions of the metal ion with hydroxylated surface sites on reactive $\mathrm{Fe}$ and $\mathrm{Al}$ oxides (Bowers and Huang, 1986; Girvin et al., 1993; Girvin et al., 1996). Such metal ion complexation has been cited as causal for the far field groundwater migration of radioactive cations $\left({ }^{60} \mathrm{Co}\right.$ and ${ }^{239 / 240} \mathrm{Pu}$ ) from subsurface disposal sites (Means et al., 1978; Killey et al., 1984). In this communication we investigate the geochemical behavior of a organic metal complex [Co(II)EDTA ${ }^{2-}$ ] selected to represent those of intermediate to high stability (e.g., $\log \mathrm{K}_{\mathrm{ML}}>15$ ). EDTA $^{4-}$ is a commonly used industrial complexant and food additive, is relatively recalcitrant to microbial degradation, has been cited as metal ion mobilizer in subsurface systems, and is an ubiq-

*Author to whom correspondence should be addressed (john.zachara@pnl.gov). uitous minor component of many diverse waste streams including low and high level nuclear waste. $\mathrm{NiEDTA}^{2-}$ released from wastewater treatment plants, for example, has been observed in San Francisco Bay (Bedsworth and Sedlak, 1999).

Under oxidizing conditions where solid phase Fe(III)-oxides are stable, Me(n)EDTA ${ }^{(4-n)-}$ complexes undergo a complex reaction suite. It includes:

1. Adsorption to hydroxylated surface sites on $\mathrm{Fe}$ and $\mathrm{Al}$ oxides (e.g., SOH);

2. Dissociation promoted by soluble $\mathrm{Fe}^{3+}$ and $\mathrm{Al}^{3+}$ that compete for EDTA ${ }^{4-}$, and hydroxylated surface sites that compete for the metal; and

3. For $\mathrm{Co}(\mathrm{II})$ specifically, oxidation to a weakly reactive, highly stable form [Co(III)EDTA ${ }^{-}$; $\left.\log \mathrm{K}=41.2\right]$ (Zachara et al., 1995a; Brooks and Jardine, 1996).

Rapid and slow reactions exist in the reaction suite (Szecsody et al., 1998a,b), and these may impart strong kinetic behavior to the phase distribution of the complex over time periods of hours to days (Szecsody et al., 1994; Zachara et al., 1995a,b). The concentrations of the ligands $\left(\mathrm{EDTA}^{4-}, \mathrm{SO}^{-}, \mathrm{SOH}_{2}^{+}\right.$) relative to the metal $\left(\mathrm{Co}^{2+}\right)$, their stability constants (log $\mathrm{K}$ 's for both aqueous and surface species), and the solubility of the 
$\mathrm{Fe}$ and $\mathrm{Al}$ containing phases are determining factors of the extent of dissociation, adsorption, and retardation.

Far less is known about the geochemical behavior of organic-metal complexes in anoxic environments. Ferrogenic conditions, the subject of this paper, are characterized by the absence of bacterial sulfate reduction and the presence of significant $\mathrm{Fe}_{(\text {aq) }}^{2+}$ (Lyngkilde and Christensen, 1992a,b; Lovley and Chapelle, 1995). Ferrogenic groundwaters are common (Chapelle, 1993), and result primarily from the enzymatic reduction of $\mathrm{Fe}(\mathrm{III})$ oxides coupled with organic matter or $\mathrm{H}_{2(\mathrm{~g})}$ oxidation by dissimilatory iron reducing bacteria (DIRB; Lovley et al., 1990; Lovley, 1993; Albrechtsen and Christensen, 1994). Significant changes occur to aquifer solids in transition from oxic to ferrogenic conditions including a depletion of poorly crystalline and crystalline Fe(III) oxides and an increase in solid associated Fe(II) (Heron et al., 1994; Heron and Christensen, 1995). The presence of $\mathrm{Fe}_{(\mathrm{aq})}^{2+}$, the depletion of reactive $\mathrm{Fe}(\mathrm{III})$ oxides and alteration of their surface properties, and the potential saturation of surfaces by sorbed $\mathrm{Fe}(\mathrm{II})$ characterize ferrogenic groundwaters/aquifer solids and are factors that may have a profound, and as yet unexplored, influence on the chemical behavior of Me(n)EDTA ${ }^{(4-n)-}$ complexes.

Studies with microbial enrichment cultures have shown that DIRB require direct contact with the $\mathrm{Fe}$ (III) oxide surface for enzymatic reduction of the solid phase (Arnold et al., 1988; Lovley et al., 1991; Myers and Nealson, 1988). Amorphic, poorly crystalline, and crystalline Fe(III) oxides are all vulnerable to DIRB reduction (Arnold et al., 1988; Phillips et al., 1993; Roden and Zachara, 1996; Fredrickson et al., 1998; Zachara et al., 1998). Surface chemistry appears to influence the bioreduction of goethite and hematite, as the microbial reduction rate slows as the surface reaches apparent saturation with sorbed $\mathrm{Fe}^{2+}$ (Roden and Zachara, 1996). Aqueous complexants stimulate bacterial reduction of crystalline Fe(III) oxides by drawing $\mathrm{Fe}$ (II) from the surface (Urrutia et al., 1998; Urrutia et al., 1999). In subsurface materials, fine grained amorphic and cryptocrystalline Fe(III) oxides may be preferentially dissolved by DIRB, while the surfaces of more crystalline phases may be transformed to a $\mathrm{Fe}$ (II)-like phase.

We have previously investigated the influence of adsorption, dissociation, and oxidation on the geochemical behavior of Co(II)EDTA ${ }^{2-}$ in oxidized subsurface sediments (Zachara et al., 1995a,b). Here, we extend those findings to anoxic conditions representative of $\mathrm{Fe}^{2+}$ containing groundwaters. Ferrogenic conditions were generated in anoxic suspensions of goethite and a goethite-containing subsurface sediment through the addition of $\mathrm{Fe}_{(\mathrm{aq})}^{2+}$, and biotically through inoculation with $\operatorname{DIRB}\left(S\right.$. alga, strain BrY) and an electron donor $\left(\mathrm{H}_{2(\mathrm{~g})}\right)$. Chemically unreactive electrolytes, buffer, and media were chosen to minimize complexity. The biologic experiments were conducted under non-growth conditions by withholding phosphate (except in one case), trace metals, and vitamins to avoid complications resulting from abiotic reactions with nutrients and cell division, etc. The geochemical behavior of $\mathrm{Co}$ (II)EDTA ${ }^{2-}$ was determined as a function of time and $\mathrm{Fe}^{2+}$ concentration, emphasizing surface complexation and aqueous dissociation reactions controlling chemical distribution between the aqueous and solid phase.

\section{EXPERIMENTAL PROCEDURES}

\subsection{Stock Solutions and Sorbates}

Stock solutions of $10^{-2} \mathrm{~mol} / \mathrm{L} \mathrm{Co}^{2+}$ and $10^{-1} \mathrm{~mol} / \mathrm{L} \mathrm{EDTA}^{4-}$ were prepared using $\mathrm{Co}\left(\mathrm{ClO}_{4}\right)_{2} \cdot 6 \mathrm{H}_{2} \mathrm{O}$ (Pfaltz and Bauer, Inc., Waterbury, CT) and $\mathrm{C}_{10} \mathrm{H}_{14} \mathrm{~N}_{2} \mathrm{Na}_{2} \mathrm{O}_{8} \cdot 2 \mathrm{H}_{2} \mathrm{O}$ [EDTA, disodium salt, dihydrate (JT Baker Chemical Co., Phillipsburg, NJ)] and deionized, distilled water (DDW). The concentrations were verified by ICP analysis of Co and $\mathrm{Na}$, respectively. Dilutions were prepared to yield solutions of $10^{-3}$ $\mathrm{mol} / \mathrm{L} \mathrm{Co}^{2+}$, EDTA ${ }^{4-}$ or Co(II)EDTA ${ }^{2-}$. Radioactive cobalt $\left({ }^{60} \mathrm{Co}\right.$ as $\mathrm{CoCl}_{2}, 90.55 \mathrm{mCi} / \mathrm{mg}, 99 \%$ radiochemical purity, DuPont, Wilmington, DE) and EDTA ${ }^{4-}\left({ }^{14} \mathrm{C}\right.$ as ethylenediaminetetraacetic acid [acetic$\left.1-{ }^{14} \mathrm{C}\right], 4.5 \mathrm{mCi} / \mathrm{mmol},>99 \%$ purity, ICN Biomedicals, Inc., Irvine, CA) were added to yield $10^{6} \mathrm{cpm} / \mathrm{mL}$ for radiochemical determination of aqueous phase ${ }^{60} \mathrm{Co}$ and/or ${ }^{14} \mathrm{C}$.

Stock solutions of $10^{-2} \mathrm{~mol} / \mathrm{L} \mathrm{Fe}^{2+}$ and $10^{-1} \mathrm{~mol} / \mathrm{L} \mathrm{EDTA}^{4-}$ were prepared in an anoxic chamber using $\mathrm{Fe}\left(\mathrm{ClO}_{4}\right)_{2} \cdot 6 \mathrm{H}_{2} \mathrm{O}$ (Johnson Matthey Co. Inc., Ward Hill, MA) and $\mathrm{C}_{10} \mathrm{H}_{14} \mathrm{~N}_{2} \mathrm{Na}_{2} \mathrm{O}_{8} \cdot 2 \mathrm{H}_{2} \mathrm{O}$ [EDTA, disodium salt, dihydrate (JT Baker Chemical Co., Phillipsburg $\mathrm{NJ}$ )] and degassed, DDW. The solution $\mathrm{pH}$ was adjusted to 6.5 using $\mathrm{CO}_{2}$-free $\mathrm{NaOH}$ and passed through a $0.2 \mu \mathrm{m}$ filter. The concentrations were verified by ICP analysis of $\mathrm{Fe}$ and $\mathrm{Na}$. Dilutions were prepared to yield the desired concentrations of $\mathrm{Fe}^{2+}, \mathrm{EDTA}^{4-}$ or Fe(II)EDTA ${ }^{2-}$. Radioactive $\mathrm{Fe}^{2+}\left({ }^{59} \mathrm{Fe}\right.$ as $\mathrm{FeSO}_{4}, 23.76 \mathrm{mCi} / \mathrm{mg}$, 99\% radiochemical purity, DuPont, Wilmington, DE) and EDTA ${ }^{4-}\left({ }^{14} \mathrm{C}\right.$ as ethylenediaminetetraacetic acid [acetic- $1-{ }^{14} \mathrm{C}$ ] $4.5 \mathrm{mCi} / \mathrm{mmol},>99 \%$ purity, ICN Biomedicals, Inc., Irvine, CA) were added to yield $10^{6} \mathrm{cpm} / \mathrm{mL}$.

\subsection{Sorbents}

Goethite was synthesized by combining $0.2 \mathrm{~L}$ of $1 \mathrm{~mol} / \mathrm{L} \mathrm{Fe}\left(\mathrm{NO}_{3}\right)_{3}$ with $1.8 \mathrm{~L}$ of $1 \mathrm{~mol} / \mathrm{L} \mathrm{KOH}$ (Schwertmann et al., 1985) in an acidwashed 4 L HDPE Nalgene ${ }^{\circledR}$ bottle. The bottle was placed in a static position in an oven at $75^{\circ} \mathrm{C}$ for $7 \mathrm{~d}$.

The goethite was washed to remove residual $\mathrm{NO}_{3}^{-}$and extracted five times with acidified $(0.25 \mathrm{~mol} / \mathrm{L} \mathrm{HCl})$ hydroxylamine $\left(\mathrm{NH}_{2} \mathrm{OH} \cdot \mathrm{HCl}\right)$ at $50^{\circ} \mathrm{C}$ to remove residual ferrihydrite. After extraction, the goethite was washed $2 \times$ with $0.03 \mathrm{~mol} / \mathrm{L} \mathrm{Ca}\left(\mathrm{ClO}_{4}\right)_{2}$ resuspended in DDW, transferred to SpectraPor ${ }^{\circledR} 1000$ MWCO tubing and dialyzed against DDW until the conductivity of the outside solution was $<5 \mu \mathrm{mho} / \mathrm{cm}$. The suspension was lyophilized, and lightly crushed to pass an 850mesh sieve. The resulting goethite had a surface area of $55.4 \mathrm{~m}^{2} / \mathrm{g}$ measured by the $\mathrm{N}_{2}$ B.E.T. method.

A bulk sample of subsurface sediment was obtained in a sand pit at a depth of $2 \mathrm{~m}$ from the Pleistocene-age, Columbia formation near Milford, DE. The sand textured sediment was weakly cohesive with grains cemented by Fe(III) oxides (primarily goethite). The sand mineralogy was dominated by quartz and weathered feldspars. The sediment was air dried and sieved to $<2 \mathrm{~mm}$. Selected characteristics of the sediment are shown in Table 1. A more complete description of the origin, sampling, and mineralogic analyses of this sediment were presented in Zachara et al. (1995b; Zachara et al., 1998).

\subsection{Abiotic Experiments}

\subsection{1. pH-dependent $\mathrm{Fe}(I I)$ sorption}

A known mass of Milford sediment was placed in $50 \mathrm{~mL}$ polycarbonate centrifuge tubes or Nalgene HDPE bottles and passed into an anoxic chamber. The anoxic chamber used throughout this study was equipped with an oxygen meter. Oxygen sensitive experiments were performed when the $\mathrm{O}_{2}$ meter read $0.0 \mathrm{ppm} \mathrm{O}_{2}$. Dissolved $\mathrm{O}_{2}$ measurements were not made. Degassed, electrolyte solution $[0.003 \mathrm{~mol} / \mathrm{L}$ $\left.\mathrm{Ca}\left(\mathrm{ClO}_{4}\right)_{2}\right]$ was added to achieve the desired solid:soluton ratio. $\mathrm{HClO}_{4}$ or $\mathrm{NaOH}$ were added to duplicate tubes to achieve eleven target $\mathrm{pH}$ values between 3.5 and 9.5. Following overnight equilibration, the suspensions were re-adjusted to their target $\mathrm{pH}$. This cycle was repeated until $\mathrm{pH}$ drift was $<0.5 \mathrm{pH}$ unit during the overnight equilibration. Vigorous, prolonged mixing of the suspensions was minimized. Once $\mathrm{pH}$ equilibration was achieved, the suspensions were washed twice with degassed, $\mathrm{pH}$-adjusted $0.003 \mathrm{~mol} / \mathrm{L} \mathrm{Ca}\left(\mathrm{ClO}_{4}\right)_{2}$ to reduce the concentration of dissolution products in solution. Following the last wash, $\mathrm{pH}$-adjusted electrolyte was quantitatively added to each tube to 
Table 1. Selected properties of the Milford sediment.

\begin{tabular}{|c|c|c|c|c|c|}
\hline \multirow{3}{*}{$\begin{array}{c}\mathrm{N}_{2} \text {-surface are } \\
\left(\mathrm{m}^{2} / \mathrm{g}\right)\end{array}$} & \multicolumn{3}{|c|}{ Extractable $\mathrm{Fe}$} & \multirow{3}{*}{$\begin{array}{c}\text { Silt and Clay } \\
\%\end{array}$} & \multirow[b]{3}{*}{ Mineralogy } \\
\hline & $\mathrm{NH}_{2} \mathrm{OH} \cdot \mathrm{HCl}^{\mathrm{a}}$ & $\mathrm{NH}_{4} \mathrm{Ox}^{\mathrm{b}}$ & $\mathrm{DCB}^{\mathrm{c}}$ & & \\
\hline & \multicolumn{3}{|c|}{ (umol/g) } & & \\
\hline 6.83 & 0.87 & 2.78 & 40.2 & 3.2 & $\begin{array}{l}\text { Quartz, K-feldspar, }{ }^{\mathrm{d}} \text { trace } \\
\text { rutile, and magnetite }{ }^{\mathrm{d}}{ }^{\mathrm{c}} \\
\text { kaolinite and goethite }^{\mathrm{e}}\end{array}$ \\
\hline $\begin{array}{l}\text { a Acidified hy } \\
\text { b Ammonium } \\
{ }^{c} \text { Dithionite-ci } \\
\text { d Sand sized f } \\
\text { e Silt and }\end{array}$ & $\begin{array}{l}\text { e hydrochloride. } \\
\text { dark. } \\
\text { ponate. }\end{array}$ & & & & \\
\hline
\end{tabular}

yield the desired solid:solution ratio. A variety of different solids concentrations were used depending on the sorbate. These ranged between $33 \mathrm{~g} / \mathrm{L}$ and $500 \mathrm{~g} / \mathrm{L}$ with specific values noted in the figures and captions.

A stock suspension of goethite was prepared in an anoxic chamber using degassed electrolyte solution $\left[0.003\right.$ or $\left.0.03 \mathrm{~mol} / \mathrm{L} \mathrm{Ca}\left(\mathrm{ClO}_{4}\right)_{2}\right]$. Aliquots of the suspension were transferred to tarred $50 \mathrm{~mL}$ Oakridge tubes and the suspension mass determined. $\mathrm{HClO}_{4}$ and $\mathrm{NaOH}$ were added to duplicate tubes to achieve target $\mathrm{pH}$ 's ranging from 2.0 to 9.5 . Typically $0.5 \mathrm{~g} / \mathrm{L}$ goethite was used for the sorption experiments. Changes from this concentration are noted when they occurred. The $\mathrm{pH}$ adjustment process followed that described for the Milford sediment.

Ferrous iron was added to the $\mathrm{pH}$ adjusted suspensions as $10^{-3}$ $\mathrm{mol} / \mathrm{L} \mathrm{Fe}^{2+}$ or the preformed $\mathrm{Fe}(\mathrm{II}) \mathrm{EDTA}^{2-}$ complex to yield a diluted initial concentration of $10^{-5} \mathrm{~mol} / \mathrm{L}$. The suspensions were equilibrated by rotating at $80 \mathrm{rpm}$ for 4 to $16 \mathrm{~h}$ in a light-excluded environmental chamber $\left(25^{\circ} \mathrm{C}\right)$. Phase separation was accomplished by centrifugation at $5000 \mathrm{rcf}$ for $30 \mathrm{~min}$. Aqueous concentrations of ${ }^{14} \mathrm{C}$ and ${ }^{59} \mathrm{Fe}$ were determined in the supernatant. Because dual-label counting techniques could not be used for the simultaneous determination of ${ }^{14} \mathrm{C}$ and ${ }^{59} \mathrm{Fe}$, duplicate experiments were conducted with either ${ }^{14} \mathrm{C}$-labelled EDTA $^{4-}$ and stable $\mathrm{Fe}^{2+}$, or non-labeled EDTA ${ }^{4-}$ and ${ }^{59} \mathrm{Fe}^{2+}$. A Ross semimicro combination $\mathrm{pH}$ electrode was used to determine the $\mathrm{pH}$ of the equilibrated solution.

Aqueous concentrations of $\mathrm{Al}, \mathrm{Fe}$, and $\mathrm{Si}$ in the Milford supernatants and $\mathrm{Fe}$ in the goethite supernatants were determined using ICP-AES on subsamples that had been passed through a $18 \AA$ filter (Amicon Centriflo $^{\circledR}$ membrane cones; Danver, MA). Prior to sample filtration, the membrane cones were soaked in $\mathrm{pH} 2 \mathrm{DDW}$ ( $\mathrm{pH}$ adjusted with $\mathrm{HNO}_{3}$ ) for $1 \mathrm{~h}$ and rinsed twice with centrifugation using DDW. The first $4 \mathrm{~mL}$ of sample filtrate were discarded and the following $4 \mathrm{~mL}$ was combined with $200 \mu \mathrm{L}$ of concentrated Ultrex ${ }^{\circledR} \mathrm{HNO}_{3}$ for sample preservation.

\subsection{2. pH-Dependent adsorption of Co(II)EDTA ${ }^{2-}$}

The $\mathrm{pH}$ variable adsorption of Co(II)EDTA ${ }^{2-}$ at $10^{-5} \mathrm{~mol} / \mathrm{L}$ was measured identically to $\mathrm{Fe}(\mathrm{II}) \mathrm{EDTA}^{2-}$ except that dual label counting $\left({ }^{60} \mathrm{Co},{ }^{14} \mathrm{C}\right)$ was used to simultaneously quantify sorption of both analytes.

\subsubsection{Adsorption isotherms of $\mathrm{Fe}^{2+}$ and $\mathrm{Co}^{2+}$}

Adsorption isotherms were measured on the Milford sediment and goethite over a concentration range of $10^{-7}$ to $10^{-2} \mathrm{~mol} / \mathrm{L}$ at $\mathrm{pH}$ values relevant to the biotic reduction experiments. A $0.003 \mathrm{~mol} / \mathrm{L} \mathrm{Ca}\left(\mathrm{ClO}_{4}\right)_{2}$ background electrolyte was used that was buffered at $\mathrm{pH} 6.5$ in some cases with $0.01 \mathrm{~mol} / \mathrm{L}$ PIPES [piperazine-N, N'-bis(2-ethanesulfonic acid)]. Electrolyte and sorbate solutions were prepared in an anoxic chamber using degassed, DDW. Ferrous iron solutions spiked with ${ }^{59} \mathrm{Fe}^{2+}$ were prepared as previously described. All stages of preparation and sampling were conducted in an anoxic chamber. Sorbents were degassed in the anoxic chamber for at least one week prior to contact with $\mathrm{Fe}_{(\text {aq) }}^{2+}$. Various sorbent concentrations were used depending on the sorbate and method of analysis. The synthetic goethite was used at $0.05,0.1,0.25$, and $0.5 \mathrm{~g} / \mathrm{L}$ and the Milford sediment at 10,50 , and 500 $\mathrm{g} / \mathrm{L}$. Only sealed reaction vessels were removed from the anoxic chamber for determination of mass or during equilibration (under an $\mathrm{N}_{2}$ atmosphere). Suspensions were equilibrated at $25^{\circ} \mathrm{C}$ for $16 \mathrm{~h}$ on a tabletop shaker $(80 \mathrm{rpm})$, and were sampled and analyzed as described for the $\mathrm{pH}$ edges.

\subsubsection{Effect of $\mathrm{Fe}_{(a q)}^{2+}$ on $\mathrm{Co}(\mathrm{II}) \mathrm{EDTA}^{2-}$ sorption}

To simulate the potential effects of bacterial Fe(III) oxide reduction on $\mathrm{Co}$ (II)EDTA ${ }^{2-}$ sorption, $\mathrm{Fe}_{(\mathrm{aq})}^{2+}$ was metered [at concentrations of $10^{-3}, 10^{-4}, 10^{-5}$, and $10^{-6} \mathrm{~mol} / \mathrm{L} \mathrm{Fe}^{2+}$ ] into Co(II)EDTA ${ }^{2-}\left(10^{-5}\right.$ $\mathrm{mol} / \mathrm{L}$ ) suspensions with goethite and the Milford sediment at two different initial $\mathrm{pH}$ values. The $\mathrm{pH}$ values and the sorbent concentrations were selected so that approximately $75-80 \%$ of the Co(II)EDTA ${ }^{2-}$ would be adsorbed at the lower $\mathrm{pH}$ and $<50 \%$ would be adsorbed at the higher $\mathrm{pH}$. All stages of preparation and sampling were conducted in an anoxic chamber.

A sorbent concentration of $0.5 \mathrm{~g} / \mathrm{L}$ for goethite and $500 \mathrm{~g} / \mathrm{L}$ for the Milford sediment was used which included either $0.003 \mathrm{~mol} / \mathrm{L} \mathrm{Ca}-$ $\left(\mathrm{ClO}_{4}\right)_{2}$ as the background electrolyte or $0.003 \mathrm{~mol} / \mathrm{L} \mathrm{Ca}\left(\mathrm{ClO}_{4}\right)_{2}$ and $0.01 \mathrm{~mol} / \mathrm{L}$ PIPES as a $\mathrm{pH}$ buffer. The suspension $\mathrm{pH}$ values were adjusted to values of approximately 5.5 and 7.0 for goethite and 6.0 and 7.5 for the Milford, both of which were re-adjusted for several days to ensure initial $\mathrm{pH}$ stability. The electrolyte was replaced before sorbate spiking first with $\mathrm{Fe}_{(\mathrm{aq})}^{2+}$ and second [after $1 \mathrm{~h}$ equilibration with $\mathrm{Fe}^{2+}$ ] with Co(II)EDTA ${ }^{2-}$. Suspensions were equilibrated for $16 \mathrm{~h}$ shaken at $80 \mathrm{rpm}$ and $25^{\circ} \mathrm{C}$ before sampling and analyzing as previously described. Aqueous $\mathrm{Fe}^{2+}$ concentrations in the equilibrium solution were determined by ICP-AES in $18 \AA$ filtrates.

\subsection{Microbiologic Experiments}

\subsubsection{Bacterial media, cultivation, and cell preparation}

The dissimilatory iron reducing bacteria, S. alga, strain BrY (Caccavo et al., 1992; Roselló-Mora et al., 1994; Roden and Zachara, 1996; Urrutia et al., 1998), was used to promote Fe(III) oxide reduction. $S$. alga was maintained on tryptic soy agar slants $[30 \mathrm{~g} / \mathrm{L}$ tryptic soy broth (TSB), $15 \mathrm{~g} / \mathrm{L}$ agar; Difco Laboratories, Detroit, MI] incubated aerobically at $30^{\circ} \mathrm{C}$, and cultured for routine use in TSB medium on a rotary shaker $(200 \mathrm{rpm})$ at $37^{\circ} \mathrm{C}$. The cell suspension was grown for $16 \mathrm{~h}$ to late $\log$ phase. Two hours prior to inoculation of the mineral suspension, the bacterial culture was harvested by centrifugation at $6930 \mathrm{rcf}$ for $15 \mathrm{~min}$ at $10^{\circ} \mathrm{C}$. The cell pellet was resuspended in sterile deionized water and centrifuged again. Following the second centrifugation, the cell pellet was resuspended in sterile DDW to yield the desired cell concentration. The bacterial cell density was determined using the $\mathrm{A}_{600}$ of a 4-fold dilution.

To further prepare the cells for inoculation into mineral suspensions, the culture was transferred to an $\mathrm{N}_{2}$-sparged, autoclaved serum bottle. A sterile, $15 \mathrm{~cm}$ spinal tap needle (18 gauge) connected to a sterile, 
cotton-filled syringe through which $\mathrm{N}_{2}$ was flowing was inserted through the stopper of the serum bottle until the tip was submerged in the cell culture medium. The spinal needle and serum stopper was swabbed with ethanol as the needle was pushed into the bottle. Another needle, connected to a sterile, cotton-filled syringe was then pushed through the stopper to provide a gas outlet, and the medium in the bottle was purged for about $20 \mathrm{~min}$. Aliquots of $0.5 \mathrm{~mL}$ cell culture were added to the sediment suspensions to initiate the experiments. Unless specified otherwise, the initial cell density in the sediment suspensions was about $10^{8}$ cells $/ \mathrm{mL}$. All cell additions were performed with sterile syringes and needles that had been flushed with sterile, $\mathrm{O}_{2}$-free $\mathrm{N}_{2}$.

\subsubsection{Incubation of $\mathrm{Co}(I I) E D T A^{2-}$ with $\mathrm{BrY}$ and goethite}

Two experiments were conducted with laboratory synthesized goethite incubated anaerobically with $\mathrm{BrY}$ in $0.003 \mathrm{~mol} / \mathrm{L} \mathrm{Ca}\left(\mathrm{ClO}_{4}\right)_{2}$. The experiments were performed in $30 \mathrm{~mL}$ Cortex ${ }^{\circledR}$ centrifuge tube with an approximate $20 \mathrm{~mL}$ total suspension volume after inoculation and spiking. The suspension $\mathrm{pH}$ was adjusted to 6.5 using $\mathrm{NaOH}$. In the first experiment, goethite was used at $1.5 \mathrm{~g} / \mathrm{L}$ and $\mathrm{BrY}$ at a cell density of $1 \times 10^{8}$ cells $/ \mathrm{mL}$. The second experiment used $1.0 \mathrm{~g} / \mathrm{L}$ goethite and a BrY density of about $6 \times 10^{8}$ cells $/ \mathrm{mL}$.

The glass reaction vessels with goethite suspension were closed with septum caps fitted with an inverted \#20 Bellco rubber septum. To selected tubes, a $0.5 \mathrm{~mL}$ aliquot of $\mathrm{BrY}$ cell suspension and/or $0.1 \mathrm{~mL}$ of equimolar Co(II)EDTA ${ }^{2-}$ solution labeled with ${ }^{14} \mathrm{C}$ and ${ }^{60} \mathrm{Co}$ were added. Experimental controls included treatments without the BrY inoculum and/or treatments without radio-labeled Co(II)EDTA ${ }^{2-}$. The target Co(II)EDTA ${ }^{2-}$ concentration was $10^{-5} \mathrm{~mol} / \mathrm{L}$. After the addition of bacteria and Co(II)EDTA ${ }^{2-}$ to the suspensions, approximately $9 \mathrm{~mL}$ of headspace atmosphere was aseptically removed and replaced with 10 $\mathrm{mL}$ of sterile, ultrapure $\mathrm{H}_{2}$. The headspace in the tubes was maintained anaerobic throughout the experiment. Incubation occurred in the dark at $25^{\circ} \mathrm{C}$ with occasional shaking.

At the desired time intervals, tubes were centrifuged at $5000 \mathrm{rcf}$ for $10 \mathrm{~min}$ and the supernatant was sampled for ${ }^{14} \mathrm{C}$ and ${ }^{60} \mathrm{Co}$ and other analytes (e.g., $\mathrm{Fe}$ and $\mathrm{Al}$ after $18 \AA$ filtration). The $\mathrm{pH}$ of the supernatant was measured using a combination $\mathrm{pH}$ electrode (Microelectrodes, Inc.; Londonderry, $\mathrm{NH}$ ) in $\mathrm{O}_{2}$-free atmosphere.

Inoculated and non-inoculated control suspensions were sampled for $\mathrm{HCl}$-extractable $\mathrm{Fe}(\mathrm{II})$ at each sampling point, a measure of total biogenic Fe(II) (Fredrickson et al., 1998). The oxide/sediment suspension was combined with Ultrex ${ }^{\circledR} \mathrm{HCl}$ to yield a $0.5 \mathrm{~mol} / \mathrm{L} \mathrm{HCl}$ concentration, mixed and allowed to sit overnight $(16 \mathrm{~h})$. The suspension was re-mixed and filtered through a $0.22 \mu \mathrm{m}$ syringe filter. The first $5 \mathrm{~mL}$ of filtrate were discarded. The $\mathrm{Fe}$ (II) concentration of the filtrate was measured by adding an aliquot of the filtrate with ferrozine in $50 \mathrm{mmol} / \mathrm{L}$ HEPES ( $N$-2-hydroxytheylpiperazine- $N$-2-ethanesulfonic acid) buffer. The $A_{562}$ of the sample was determined and compared to $\mathrm{Fe}(\mathrm{II})$ standards prepared from ferrous ammonia sulfate and treated similarly.

\subsubsection{Incubation of $\mathrm{Co}(I I) E D T A^{2-}$ with $\mathrm{BrY}$ and the Milford sediment}

Six $\mathrm{g}$ of Milford sediment were added to $30 \mathrm{~mL}$ Corex ${ }^{\circledR}$ centrifuge tubes with $13.9 \mathrm{~mL}$ of anaerobic solution containing $0.003 \mathrm{~mol} / \mathrm{L}$ $\mathrm{Ca}\left(\mathrm{ClO}_{4}\right)_{2}$. The $\mathrm{pH}$ of the sediment suspension was adjusted to 6.5. The tubes were closed with septum caps fitted with an inverted \#20 Bellco ${ }^{\mathrm{TM}}$ rubber septum. The suspensions were allowed to rest for $48 \mathrm{~h}$ to ensure $\mathrm{pH}$ stability. The tubes were inoculated with $\operatorname{BrY}\left(6 \times 10^{8}\right.$ cells $\left./ \mathrm{mL}\right)$, spiked with Co(II)EDTA ${ }^{2-}$, incubated, and sampled/analyzed as described for goethite in 2.4.2.

\subsubsection{Incubation of $\mathrm{Co}(\mathrm{II}) E D T A^{2-}$ with $\mathrm{BrY}$, malate, and the Milford sediment}

This experiment was performed like 2.4 .3 with the exceptions that $\mathrm{pH}$ was adjusted with $\mathrm{NH}_{4} \mathrm{OH}$, and $0.03 \mathrm{~mol} / \mathrm{L}$ sodium malate and $5 \times$ $10^{-5} \mathrm{~mol} / \mathrm{L} \mathrm{KH}_{2} \mathrm{PO}_{4}$ were added to the anaerobic media. In this case only, an attempt was made to stimulate growth by addition of a C-source (malate) and supplementary $\mathrm{N}$ and $\mathrm{P}$.

\subsection{5. pH-dependent sorption of $C o(I I) E D T A^{2-}$ on microbially-reduced Milford sediment}

Suspensions containing $6 \mathrm{~g}$ of Milford sediment and $12 \mathrm{~mL}$ of 0.003 $\mathrm{mol} / \mathrm{L} \mathrm{Ca}\left(\mathrm{ClO}_{4}\right)_{2}$ were prepared, and their $\mathrm{pH}$ was adjusted to $\sim 6.5$. $\mathrm{BrY}$ cells were inoculated to yield $1 \times 10^{8}$ cells $/ \mathrm{mL}, \mathrm{H}_{2(\mathrm{~g})}$ was added as electron donor, and the tubes equilibrated as described previously. The HCl-extractable $\mathrm{Fe}(\mathrm{II})$ of the suspension was monitored with time to establish the extent of $\mathrm{Fe}(\mathrm{III})$ reduction. At $14 \mathrm{~d}$ after inoculation with $\mathrm{BrY}$, it was determined that the extent of $\mathrm{Fe}(\mathrm{III})$ reduction was maximized at approximately $12 \%$ of the total goethite $\mathrm{Fe}(\mathrm{III})$. An identical series of tubes containing Milford sediment and solution were mixed and equilibrated without $S$. alga. This treatment allowed comparison of the sorption characteristics of the reduced to the unreduced material.

On day 14 , the suspensions were washed with $0.3 \mathrm{~mol} / \mathrm{L} \mathrm{Ca}\left(\mathrm{ClO}_{4}\right)_{2}$ to remove loosely attached bacterial cells and aqueous/exchangeable $\mathrm{Fe}^{2+}$. The washing procedure involved centrifugation; removal of supernatant solution under anaerobic conditions; replacement of the supernatant with fresh, anoxic electrolyte; resuspension of the sediment; and sonication for $5 \mathrm{~min}$. The washing step was performed 3 times. After the final wash, the electrolyte was replaced and $\mathrm{pH}$ adjustment of the suspensions was initiated. The suspension $\mathrm{pH}$ was adjusted to a range of values (between $\mathrm{pH}=3.5$ and 9.5) daily using either $\mathrm{NaOH}$ or $\mathrm{HClO}_{4}$. After five days, the desired pHs were approximately achieved. Radio-labeled, equimolar Co(II)EDTA ${ }^{2-}$ was added to yield $10^{-5} \mathrm{~mol} / \mathrm{L}$. After a $16 \mathrm{~h}$ equilibration with gentle mixing in the dark, the suspensions were centrifuged at $650 \mathrm{rcf}$ for $1 \mathrm{~h}$. The supernatant was sampled for ${ }^{14} \mathrm{C}$ and ${ }^{60} \mathrm{Co}$ and $\mathrm{pH}$ as described previously.

\section{RESULTS}

\subsection{Identification of Chemical Components and Species}

S. alga, strain BrY, produces Fe(II) in anoxic suspensions of goethite and the Milford sediment in the presence of an appropriate e-donor (Roden and Zachara, 1996; Urrutia et al., 1998). As $\mathrm{Fe}_{(\mathrm{aq})}^{2+}$ is evolved, the speciation of $\mathrm{Co}(\mathrm{II}) \mathrm{EDTA}_{(\mathrm{aq})}^{2-}$ may change. Shown in Table 2 are the computed effects of $\mathrm{Fe}_{(\mathrm{aq})}^{2+}$ on the species distribution of $\mathrm{Co}(\mathrm{II}) \mathrm{EDTA}_{(\mathrm{aq})}^{2-}\left(1.0 \times 10^{-5} \mathrm{~mol} / \mathrm{L}\right)$ at $\mathrm{pH} 6.75$ using the aqueous complexation constants in Table 3. The range in $\left[\mathrm{Fe}^{2+}\right]_{\mathrm{T}}$ represents that observed by Roden and Zachara (1996). Increasing concentrations of $\mathrm{Fe}_{(\mathrm{aq})}^{2+}$ induce $\mathrm{Co}(\mathrm{II}) \mathrm{EDTA}_{(\mathrm{aq})}^{2-}$ dissociation at equilibrium, yielding a mixture of $\mathrm{Co}(\mathrm{II}) \mathrm{EDTA}_{(\mathrm{aq})}^{2-}, \mathrm{Co}_{(\mathrm{aq})}^{2+}, \mathrm{Fe}_{(\mathrm{aq})}^{2+}$, and $\mathrm{Fe}(\mathrm{II}) \mathrm{EDTA}_{(\mathrm{aq})}^{2-}$. The dissociation of Co(II)EDTA $($ aq) molar excess of $\mathrm{Fe}_{(\mathrm{aq})}^{2+}$ at its higher concentrations $\left(10^{-4}-10^{-3}\right.$ $\mathrm{mol} / \mathrm{L}$ ) because of the higher stability constant of $\mathrm{Co}(\mathrm{II})$ $\operatorname{EDTA}_{(\mathrm{aq})}^{2-}($ Table 3).

The dissociative effects of $\mathrm{Fe}_{(\mathrm{aq})}^{2+}$ are shown for example only in Table 2, as the actual effects will be influenced by adsorption. Sorption of $\mathrm{Co}^{2+}$ to goethite enhances the extent of $\mathrm{Co}(\mathrm{II}) \mathrm{EDTA}_{(\mathrm{aq})}^{2-}$ dissociation, as surface $\mathrm{SOH}$ sites strongly compete with $\mathrm{EDTA}^{4-}$ for the metal. Ferrous iron sorption decreases $\mathrm{Co}(\mathrm{II}) \mathrm{EDTA}_{(\mathrm{aq})}^{2-}$ dissociation by reducing $\mathrm{Fe}_{(\mathrm{aq})}^{2+}$ concentrations.

\subsection{Sorption of Individual Chemical Components and Species}

Much of the experimental sorption data are presented as a concentration based distribution coefficient, $\mathrm{K}_{\mathrm{d}}\left[\mathrm{K}_{\mathrm{d}}(\mathrm{L} / \mathrm{g})=\right.$ total sorbed concentration ( $\mathrm{mol} / \mathrm{g}$ )/total aqueous concentration $(\mathrm{mol} / \mathrm{L})]$ to allow comparisons between experiments with different sorbent concentrations. The $K_{d}$ is influenced by both 
Table 2. Computed dissociation of $10^{-5} \mathrm{~mol} / \mathrm{L} \mathrm{Co}(\mathrm{II}) \mathrm{EDTA}_{(\mathrm{aq})}^{2-}$ in response to variable $\left[\mathrm{Fe}^{2+}\right]_{\mathrm{TOT}}$ concentrations.

\begin{tabular}{|c|c|c|c|c|c|c|c|c|c|}
\hline$[\mathrm{Fe}(\mathrm{II})]_{\mathrm{TOT}}{ }^{\mathrm{a}}$ & $\begin{array}{c}\text { Co(II)EDTA }{ }^{2-} \\
(\mathrm{mol} / \mathrm{L})\end{array}$ & $\begin{array}{c}\% \\
\left(\text { of }[\mathrm{Co}]_{\mathrm{TOT}}\right. \\
\left.\&[\text { EDTA }]_{\mathrm{TOT}}\right)^{\mathrm{a}}\end{array}$ & $\begin{array}{c}\mathrm{Co}^{2+} \\
(\mathrm{mol} / \mathrm{L})\end{array}$ & $\begin{array}{c}\% \\
\left(\text { of }[\mathrm{Co}]_{\mathrm{TOT}}\right)^{1}\end{array}$ & $\begin{array}{c}\mathrm{Fe}^{2+} \\
(\mathrm{mol} / \mathrm{L})\end{array}$ & $\begin{array}{c}\% \\
\left(\text { of }[\mathrm{Fe}]_{\mathrm{TOT}}\right)^{1}\end{array}$ & $\begin{array}{c}\mathrm{Fe}(\mathrm{II}) \mathrm{EDTA}^{2-} \\
(\mathrm{mol} / \mathrm{L})\end{array}$ & $\begin{array}{c}\% \\
\left(\text { of }[\mathrm{EDTA}]_{\mathrm{TOT}}\right)^{\mathrm{a}} \text { (of }\end{array}$ & $\begin{array}{c}\% \\
\left.[\mathrm{Fe}]_{\mathrm{TOT}}\right)^{\mathrm{a}}\end{array}$ \\
\hline $1.0 \times 10^{-6}$ & $9.62 \times 10^{-6}$ & 96.2 & $3.78 \times 10^{-7}$ & 3.80 & $7.92 \times 10^{-7}$ & 79.2 & $1.38 \times 10^{-7}$ & 1.38 & 20.6 \\
\hline $5.0 \times 10^{-6}$ & $9.30 \times 10^{-6}$ & 93.0 & $6.93 \times 10^{-7}$ & 6.92 & $4.39 \times 10^{-6}$ & 87.8 & $6.02 \times 10^{-7}$ & 6.02 & 12.1 \\
\hline $1.0 \times 10^{-5}$ & $9.05 \times 10^{-6}$ & 90.5 & $9.50 \times 10^{-7}$ & 9.54 & $9.10 \times 10^{-6}$ & 91.0 & $8.86 \times 10^{-7}$ & 8.86 & 8.90 \\
\hline $5.0 \times 10^{-5}$ & $7.99 \times 10^{-6}$ & 80.0 & $1.99 \times 10^{-6}$ & 20.0 & $4.79 \times 10^{-5}$ & 95.9 & $1.96 \times 10^{-6}$ & 19.6 & 3.90 \\
\hline $1.0 \times 10^{-4}$ & $7.29 \times 10^{-6}$ & 72.9 & $2.70 \times 10^{-6}$ & 27.0 & $9.71 \times 10^{-5}$ & 97.2 & $2.68 \times 10^{-6}$ & 26.8 & 2.70 \\
\hline $5.0 \times 10^{-4}$ & $4.97 \times 10^{-6}$ & 49.7 & $5.02 \times 10^{-6}$ & 50.2 & $4.94 \times 10^{-4}$ & 98.9 & $5.00 \times 10^{-6}$ & 50.0 & 1.00 \\
\hline $1.0 \times 10^{-3}$ & $3.79 \times 10^{-6}$ & 37.9 & $6.21 \times 10^{-6}$ & 62.1 & $9.95 \times 10^{-4}$ & 99.5 & $6.19 \times 10^{-6}$ & 61.9 & 0.50 \\
\hline
\end{tabular}

${ }^{\mathrm{a}} \mathrm{TOT}=$ total component concentration.

aqueous and surface speciation; i.e., $\mathrm{K}_{\mathrm{d}}=\Sigma$ [surface species]/ [aqueous species]. Weakly sorbing aqueous species decrease $\mathrm{K}_{\mathrm{d}}$, while strongly sorbing species increase $\mathrm{K}_{\mathrm{d}}$.

\subsubsection{Goethite}

The $\mathrm{K}_{\mathrm{d}}$ for $\mathrm{Co}_{(\mathrm{aq})}^{2+}$ and $\mathrm{Fe}_{(\mathrm{aq})}^{2+}$ sorption to goethite increased with increasing $\mathrm{pH}$ (Fig. 1a) as a result of coordination to surface ligands $(\mathrm{SOH})$ in competition with the proton (Davis and Kent, 1990; Hayes and Katz, 1996).

$$
\mathrm{Me}_{(\mathrm{aq})}^{2+}+\mathrm{SOH}=\mathrm{SOMe}^{+}+\mathrm{H}^{+}
$$

The $\mathrm{Fe}_{(\mathrm{aq})}^{2+}$ ion was sorbed more strongly than $\mathrm{Co}_{(\mathrm{aq})}^{2+}$, with its sorption edge occurring 1 unit lower in $\mathrm{pH}$ (Fig. 1a). Both

Table 3. Aqueous complexation reactions. ${ }^{\mathrm{a}}$

\begin{tabular}{|c|c|}
\hline Reaction & $\begin{array}{c}\log \mathrm{K} \\
\left(\mathrm{I}=0,25^{\circ} \mathrm{C}\right)\end{array}$ \\
\hline EDTA $^{4-}+\mathrm{H}^{+}=$HEDTA $^{3-}$ & 11.03 \\
\hline $\mathrm{EDTA}^{4-}+2 \mathrm{H}^{+}=\mathrm{H}_{2} \mathrm{EDTA}^{2-}$ & 17.78 \\
\hline $\mathrm{EDTA}^{4-}+3 \mathrm{H}^{+}=\mathrm{H}_{3} \mathrm{EDTA}^{-}$ & 20.89 \\
\hline EDTA $^{4-}+4 \mathrm{H}^{+}=\mathrm{H}_{4}$ EDTA & 23.10 \\
\hline $\mathrm{EDTA}^{4-}+\mathrm{Ca}^{2+}=\mathrm{CaEDTA}^{2-}$ & 12.32 \\
\hline EDTA $^{4-}+\mathrm{Ca}^{2+}+\mathrm{H}^{+}=$CaHEDTA $^{1-}$ & 15.93 \\
\hline $\mathrm{EDTA}^{4-}+\mathrm{Co}^{2+}=\mathrm{CoEDTA}^{2-}$ & 17.97 \\
\hline $\mathrm{EDTA}^{4-}+\mathrm{Co}^{2+}+\mathrm{H}^{+}=\mathrm{CoHEDTA}^{-}$ & 21.40 \\
\hline $\mathrm{Co}^{2+}+\mathrm{H}_{2} \mathrm{O}=\mathrm{CoOH}^{+}+\mathrm{H}^{+}$ & -9.67 \\
\hline $\mathrm{Co}^{2+}+2 \mathrm{H}_{2} \mathrm{O}=\mathrm{Co}(\mathrm{OH})_{2}+2 \mathrm{H}^{+}$ & -18.76 \\
\hline $\mathrm{Co}^{2+}+3 \mathrm{H}_{2}^{2} \mathrm{O}=\mathrm{Co}(\mathrm{OH})_{3}^{-}+3 \mathrm{H}^{+}$ & -32.23 \\
\hline $\mathrm{EDTA}^{4-}+\mathrm{Al}^{3+}=\mathrm{AlEDTA}^{-}$ & 19.07 \\
\hline $\mathrm{EDTA}^{4-}+\mathrm{Al}^{3+}+\mathrm{H}^{+}=$AlHEDTA & 21.78 \\
\hline $\mathrm{EDTA}^{4-}+\mathrm{Al}^{3+}+\mathrm{H}_{2} \mathrm{O}=\mathrm{AlOHEDTA}^{2-}+\mathrm{H}^{+}$ & 12.81 \\
\hline $\mathrm{EDTA}^{4-}+\mathrm{Al}^{3+}+2 \mathrm{H}_{2} \mathrm{O}=\mathrm{Al}(\mathrm{OH})_{2} \mathrm{EDTA}^{3-}+2 \mathrm{H}^{+}$ & 2.20 \\
\hline $\mathrm{Al}^{3+}+\mathrm{H}_{2} \mathrm{O}=\mathrm{AlOH}^{2+}+\mathrm{H}^{+}$ & -4.99 \\
\hline $\mathrm{Al}^{3+}+2 \mathrm{H}_{2} \mathrm{O}=\mathrm{Al}(\mathrm{OH})_{2}^{+}+2 \mathrm{H}^{+}$ & -10.10 \\
\hline $\mathrm{Al}^{3+}+3 \mathrm{H}_{2} \mathrm{O}=\mathrm{Al}(\mathrm{OH})_{3}+3 \mathrm{H}^{+}$ & -16.00 \\
\hline $\mathrm{Al}^{3+}+4 \mathrm{H}_{2} \mathrm{O}=\mathrm{Al}(\mathrm{OH})_{4}^{-}+4 \mathrm{H}^{+}$ & -23.00 \\
\hline EDTA $^{4-}+\mathrm{Fe}^{2+}=$ FeEDTA $^{2-}$ & 15.98 \\
\hline $\mathrm{EDTA}^{4-}+\mathrm{Fe}^{2+}+\mathrm{H}^{+}=$FeHEDTA $^{-}$ & 19.11 \\
\hline $\mathrm{EDTA}^{4-}+\mathrm{Fe}^{2+}+\mathrm{H}_{2} \mathrm{O}=\mathrm{FeOHEDTA}{ }^{3-}+\mathrm{H}^{+}$ & 6.27 \\
\hline $\mathrm{Fe}^{2+}+\mathrm{H}_{2} \mathrm{O}=\mathrm{FeOH}^{+}+\mathrm{H}^{+}$ & -9.50 \\
\hline $\mathrm{Fe}^{2+}+3 \mathrm{H}_{2} \mathrm{O}=\mathrm{Fe}(\mathrm{OH})_{3}^{-}+3 \mathrm{H}^{+}$ & -31.00 \\
\hline $\mathrm{Mal}^{-2}+\mathrm{H}^{+}=\mathrm{HMal}^{-}$ & 5.10 \\
\hline $\mathrm{Mal}^{2-}+2 \mathrm{H}^{+}=\mathrm{H}_{2} \mathrm{Mal}$ & 8.56 \\
\hline $\mathrm{Mal}^{2-}+\mathrm{Ca}^{2+}=\mathrm{CaMal}$ & 2.66 \\
\hline $\mathrm{Mal}^{2-}+\mathrm{Co}^{2+}=\mathrm{CoMal}$ & 3.74 \\
\hline $\mathrm{Mal}^{2-}+\mathrm{Fe}^{2+}=\mathrm{FeMal}$ & 3.48 \\
\hline
\end{tabular}

${ }^{\text {a }}$ Smith and Martell (1977) metal ions, however, exhibited strong sorption and high $\mathrm{K}_{\mathrm{d}}$ 's over the $\mathrm{pH}$ range of the biotic experiments $(\mathrm{pH}=6-8)$.

Ferrous iron was more strongly adsorbed than $\mathrm{Co}_{(\mathrm{aq})}^{2+}$ on goethite over a wide concentration range (Fig. 1b). Parallel, slightly curvilinear isotherms were observed for $\mathrm{Co}_{(\mathrm{aq})}^{2+}$ at $\mathrm{pH}$ 6.6 and $\mathrm{pH} 7.3$, with higher sorption noted at higher $\mathrm{pH}$ as expected from Figure 1a. The isotherm of $\mathrm{Fe}_{(\mathrm{aq})}^{2+}$ was quite variable and difficult to reproduce in spite of our precautions to eliminate $\mathrm{O}_{2}$ from the experiment. The best (most consistent) of these isotherms (Fig. 1b) exhibited two part behavior (L-curve; Sposito, 1984) with steep slope at low surface concentration $\left(\log \left[\mathrm{Me}^{2+}\right]_{\text {ads }}<-4.3\right)$, and flat slope at high surface concentration indicating approach to surface saturation. The saturation values for $\mathrm{Fe}_{(\mathrm{aq})}^{2+}$ estimated according to the Langmuir convention (e.g., $K_{d}$ versus the adsorbed concentration in $\mathrm{mol} / \mathrm{g}^{2}$; Sposito, 1984) increased with increasing $\mathrm{pH}$ and yielded an average value of $10^{-3.75} \mathrm{~mol} / \mathrm{g}\left(3.23 \times 10^{-6} \mathrm{~mol} / \mathrm{m}^{2}\right)$ at the $\mathrm{pH}$ of the biotic reduction experiments. The surface saturation value $\left(3.23 \times 10^{-6} \mathrm{~mol} / \mathrm{m}^{2}\right)$ is approximately equal to the total surface site density of goethite reported by Evanko and Dzombak, (1998) and the concentration value suggested by Davis and Kent (1990) for surface complexation modeling on mineral surfaces $\left(3.84 \times 10^{-6} \mathrm{~mol} / \mathrm{m}^{2}\right)$. Lower surface saturation values for $\mathrm{Co}_{(\mathrm{aq})}^{2+}$ were estimated from the $\mathrm{Co}_{(\mathrm{aq})}^{2+}$ isotherms $\left(0.875 \times 10^{-6} \mathrm{~mol} / \mathrm{m}^{2}\right)$.

$\operatorname{Co}(\mathrm{II}) \mathrm{EDTA}_{(\mathrm{aq})}^{2-}$ sorbed as an anion, with $\mathrm{K}_{\mathrm{d}}$ 's (Co(II), EDTA $^{4-}$ ) increasing with decreasing $\mathrm{pH}$ (Fig. 1c). Various chemical reactions are summarized below and in the following sections for interpretation of results. The reactions are intended to illustrate mass action and material balance relationships rather than to infer mechanism. Reaction sequences for the $\operatorname{Me}(\mathrm{n}) \mathrm{EDTA}^{(4-\mathrm{n})-}$ series have been derived from the works of Girvin et al., (1993); Zachara et al., (1995b); Nowack et al., (1996a,b).

$\mathrm{Co}(\mathrm{II}) \mathrm{EDTA}_{(\mathrm{aq})}^{2-}$ forms a relatively weak surface complex on $\mathrm{Fe}$ (III) and Al(III) oxides that has been approximated for modeling purposes as both outer sphere and inner sphere (Zachara et al., 1995b; Nowack et al., 1996b).

$$
\mathrm{Co}(\mathrm{II}) \mathrm{EDTA}_{(\mathrm{aq})}^{2-}+\mathrm{SOH}+\mathrm{H}^{+}=\mathrm{SOH}_{2}^{+}-\mathrm{Co}(\mathrm{II}) \mathrm{EDTA}^{2-}
$$

The strength of Co(II)EDTA ${ }^{2-}$ sorption at its maximum (log $\mathrm{K}_{\mathrm{d}}=1.25$ ), was well below that noted for the metal cations $\left(\log \mathrm{K}_{\mathrm{d}}=2.5\right.$, Fig 1a). Below $\mathrm{pH}=5.5$, increasing concen- 

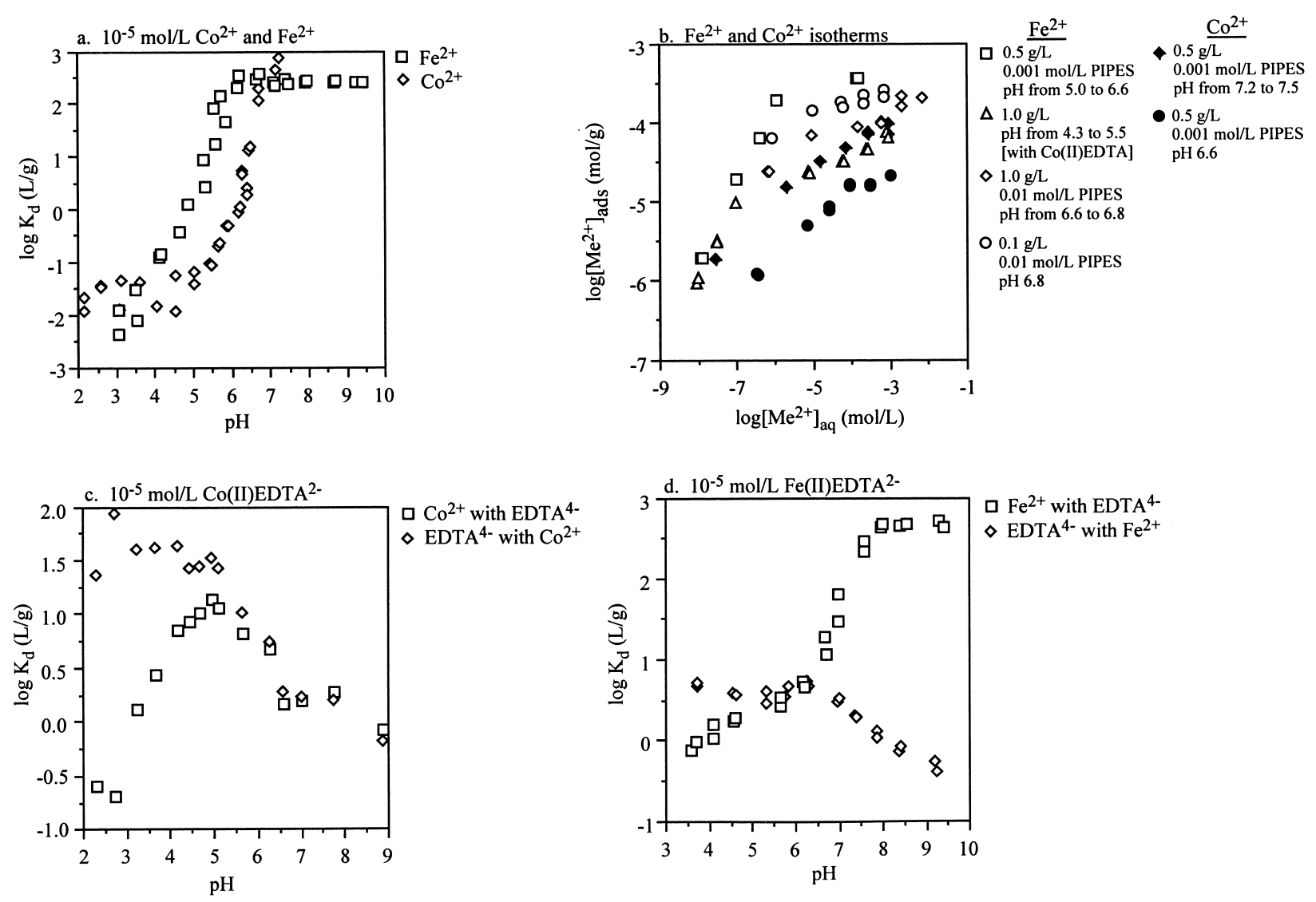

Fig. 1. Sorption behavior of $\mathrm{Co}_{(\text {aq) }}^{2+}, \mathrm{Fe}_{(\mathrm{aq}}^{2+}, \mathrm{Co}(\mathrm{II}) \mathrm{EDTA}_{(\mathrm{aq})}^{2-}$, and $\mathrm{Fe}(\mathrm{II}) \mathrm{EDTA}_{(\mathrm{aq})}^{2-}$ on goethite. Electrolyte was $0.003 \mathrm{~mol} / \mathrm{L}$ $\mathrm{Ca}\left(\mathrm{ClO}_{4}\right)_{2}$ and goethite was $0.5 \mathrm{~g} / \mathrm{L}$ unless noted otherwise. a.) $\mathrm{pH}$ sorption edges $\left(\mathrm{as} \mathrm{K}_{\mathrm{d}}\right)$ of $\mathrm{Co}_{(\mathrm{aq})}^{2+}$ and $\mathrm{Fe}_{(\mathrm{aq})}^{2+}$ on goethite. b.) adsorption isotherms of $\mathrm{Co}_{\text {(aq) }}^{2+}$ and $\mathrm{Fe}_{(\text {aq) }}^{2+}$ on goethite at different $\mathrm{pH}$ and solids concentrations. c.) $\mathrm{pH}$ sorption edge (as $\mathrm{K}_{\mathrm{d}}$ ) of $\mathrm{Co}(\mathrm{II}) \mathrm{EDTA}^{2-}$ on goethite; final $\mathrm{Co}(\mathrm{II})_{(\mathrm{aq})}$ and $\mathrm{EDTA}_{(\mathrm{aq})}^{4-}$ quantified simultaneously by dual label counting. d.) $\mathrm{pH}$ sorption edge $\left(\right.$ as $\mathrm{K}_{\mathrm{d}}$ ) of $\mathrm{Fe}(\mathrm{II}) \mathrm{EDTA}_{(\mathrm{aq})}^{2-}$ on goethite; results of two experiments where final $\mathrm{Fe}(\mathrm{II})_{(\mathrm{aq})}$ and $\mathrm{EDTA}_{(\mathrm{aq})}^{4-}$ were quantified independently.

trations of $\mathrm{Fe}_{(\mathrm{aq})}^{3+}$ solubilized from the oxide caused disparate sorption behavior of $\mathrm{EDTA}^{4-}$ and $\mathrm{Co}(\mathrm{II})$ that were initially co-associated in the complex. The $\mathrm{Fe}_{(\mathrm{aq})}^{3+}$ promoted partial dissociation of $\mathrm{Co}(\mathrm{II}) \mathrm{EDTA}_{(\mathrm{aq})}^{2-}\left(\log \mathrm{K}_{\mathrm{Fe}(\mathrm{III}) \mathrm{EDTA}}=27.91\right)$ to a mixture of $\mathrm{Fe}(\mathrm{III}) \mathrm{EDTA}_{(\mathrm{aq})}^{-}, \mathrm{Co}(\mathrm{II}) \mathrm{EDTA}_{(\mathrm{aq})}^{2-}$, and $\mathrm{Co}_{(\mathrm{aq})}^{2+}$ :

$$
\mathrm{Fe}_{(\mathrm{aq})}^{3+}+\operatorname{Co}(\mathrm{II}) \mathrm{EDTA}_{(\mathrm{aq})}^{2-}=\mathrm{Fe}(\mathrm{III}) \mathrm{EDTA}_{(\mathrm{aq})}^{-}+\mathrm{Co}_{(\mathrm{aq})}^{2+}
$$

The $\mathrm{K}_{\mathrm{d}} \mathrm{CO}(\mathrm{II})$ for $\mathrm{Co}(\mathrm{II}) \mathrm{EDTA}^{2-}$ decreased below $\mathrm{pH} 6$ because of the increasing fraction of $\mathrm{Co}_{(\mathrm{aq})}^{2+}$ (i.e., $\mathrm{K}_{\mathrm{d}}=$ $\left.[\mathrm{Co}(\mathrm{II})]_{(\text {sorbed })} /\left\{\left[\mathrm{Co}(\mathrm{II}) \mathrm{EDTA}_{(\mathrm{aq})}^{2-}+\mathrm{Co}_{(\mathrm{aq})}^{2+}\right]\right\}\right)$, which exhibited low sorptivity at these pH's (Fig. 1a).

$\mathrm{Fe}(\mathrm{II}) \mathrm{EDTA}_{(\mathrm{aq})}^{2-}$ exhibited sorption behavior similar, in part, to that observed for $\mathrm{Co}(\mathrm{II}) \mathrm{EDTA}_{(\mathrm{aq})}^{2-}$ (Fig. 1d), with differences resulting from the stronger affinity of the goethite surface for $\mathrm{Fe}_{\text {(aq) }}^{2+}$ (Fig. 1a) and the smaller aqueous complexation constant $\left(\log \mathrm{K}_{\mathrm{Fe}(\mathrm{II}) \text { EDTA }}=15.98\right)$. The competition of $\mathrm{Fe}_{(\mathrm{aq})}^{3+}$ for $\mathrm{EDTA}^{4-}$ below $\mathrm{pH} 6$ and $\mathrm{SO}^{-}$for $\mathrm{Fe}_{(\mathrm{aq})}^{2+}$ above $\mathrm{pH}=6.5$ induced more complex dissociation than noted for $\mathrm{Co}(\mathrm{II}) \mathrm{EDTA}_{(\mathrm{aq})}^{2-}$. The reaction suite is approximated as:

$$
\begin{aligned}
\mathrm{Fe}_{(\mathrm{aq})}^{3+}+\mathrm{Fe}(\mathrm{II}) \mathrm{EDTA}_{(\mathrm{aq})}^{2-}= & \mathrm{Fe}(\mathrm{III}) \mathrm{EDTA}_{(\mathrm{aq})}^{-} \\
& +\mathrm{Fe}_{(\mathrm{aq})}^{2+}(\text { below pH 5.0)(4) }
\end{aligned}
$$

$$
\begin{aligned}
\mathrm{Fe}(\mathrm{II}) \mathrm{EDTA}_{(\mathrm{aq})}^{2-} & +\mathrm{SOH}+\mathrm{H}^{+}=\mathrm{SOH}_{2}^{+}-\mathrm{Fe}(\mathrm{II}) \mathrm{EDTA}^{2-} \\
\mathrm{Fe}(\mathrm{II}) \mathrm{EDTA}_{(\mathrm{aq})}^{2-}+ & \mathrm{Ca}_{(\mathrm{aq})}^{2+}+\mathrm{SOH}=\mathrm{SOFe}^{+} \\
& +\mathrm{Ca}(\mathrm{II}) \mathrm{EDTA}_{(\mathrm{aq})}^{2-}+\mathrm{H}^{+}(\text {above } \mathrm{pH} 6.5)
\end{aligned}
$$

The $\mathrm{K}_{\mathrm{d}}$ for $\mathrm{Fe}(\mathrm{II})$ in the complex reflected aqueous speciation effects $\left(\mathrm{K}_{\mathrm{d}}=[\mathrm{Fe}(\mathrm{II})]_{(\text {sorbed })} /\left\{\left[\mathrm{Fe}(\mathrm{II}) \operatorname{EDTA}_{(\mathrm{aq})}^{2-}+\mathrm{Fe}_{(\mathrm{aq})}^{2+}\right]\right\}\right)$ and an apparent large difference in the affinity of the surface for $\mathrm{Fe}(\mathrm{II}) \mathrm{EDTA}_{(\mathrm{aq})}^{2-}$ versus $\mathrm{Fe}_{(\text {aq) }}^{2+}$. There was approximate parity in the $\mathrm{K}_{\mathrm{d}}$ 's of $\mathrm{Co}(\mathrm{II})$ and $\mathrm{Fe}(\mathrm{II})$ in the $\mathrm{EDTA}^{4-}$ complex at $\mathrm{pH} 6$ $\left(\log \mathrm{K}_{\mathrm{d}}=0.6\right)$ where $\mathrm{Me}(\mathrm{II}) \mathrm{EDTA}^{2-}$ was believed to be the primary surface species. Thus, surface complexes of $\mathrm{Fe}(\mathrm{II}) \mathrm{EDTA}^{2-}$ and Co(II)EDTA ${ }^{2-}$ appear to exhibit comparable surface binding strength.

\subsubsection{Milford sediment}

The chemical behavior of the four target solutes in contact with the Milford sediment showed comparable behavior with respect to $\mathrm{pH}$ as they did on goethite (Figs. 2a,c,d), attesting to the presence of similar sorption reactions. There were differ- 

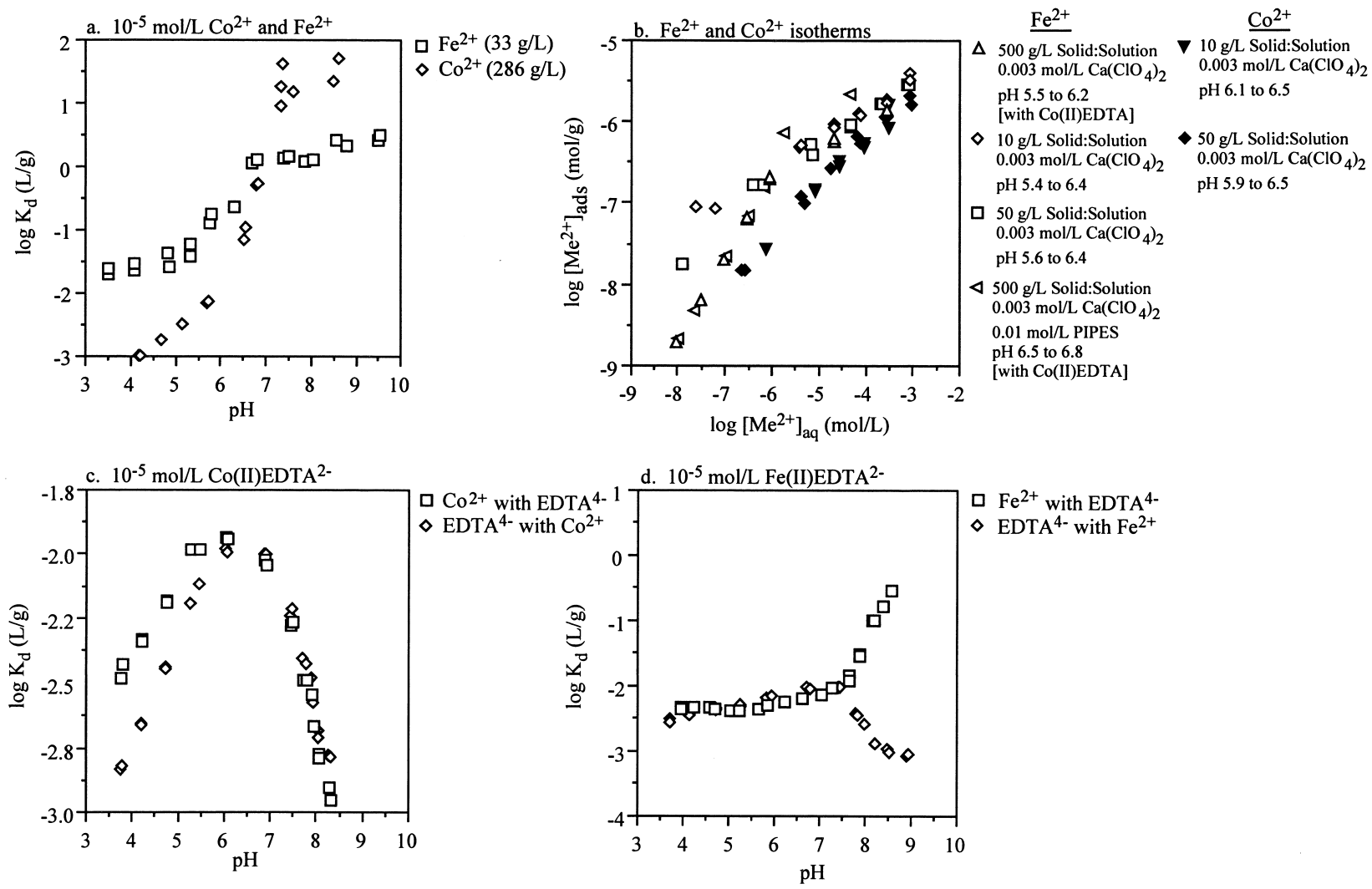

Fig. 2. Sorption behavior of $\mathrm{Co}_{(\text {aq }}^{2+}, \mathrm{Fe}_{(\text {aq) }}^{2+}, \mathrm{Co}(\mathrm{II}) \mathrm{EDTA}_{(\text {aq) }}^{2-}$, and $\mathrm{Fe}(\mathrm{II}) \mathrm{EDTA}_{(\mathrm{aq})}^{2-}$ on Milford sediment. Electrolyte was $0.003 \mathrm{~mol} / \mathrm{L} \mathrm{Ca}\left(\mathrm{ClO}_{4}\right)_{2}$ and the Milford sediment was $500 \mathrm{~g} / \mathrm{L}$ unless noted otherwise. a.) $\mathrm{pH}$ sorption edges (as $\mathrm{K}_{\mathrm{d}}$ ) of $\mathrm{Co}_{(\mathrm{aq})}^{2+}$ and $\mathrm{Fe}_{(\text {aq) }}^{2+}$ on Milford sediment. b.) adsorption isotherms of $\mathrm{Co}_{(\mathrm{aq})}^{2+}$ and $\mathrm{Fe}_{(\text {aq) }}^{2+}$ on Milford sediment at different $\mathrm{pH}$ and solids concentrations. c.) $\mathrm{pH}$ sorption edge (as $\left.\mathrm{K}_{\mathrm{d}}\right)$ of $\mathrm{Co}(\mathrm{II}) \mathrm{EDTA}^{2-}$ on Milford sediment; final Co(II) $)_{(\mathrm{aq})}$ and $\mathrm{EDTA}_{(\mathrm{aq})}^{4-}$ quantified simultaneously by dual label counting. d.) $\mathrm{pH}$ sorption edge (as $\mathrm{K}_{\mathrm{d}}$ ) of $\mathrm{Fe}(\mathrm{II}) \mathrm{EDTA}_{\text {(aq) }}^{2-}$ on Milford sediment; results of two experiments where $\mathrm{Fe}(\mathrm{II})_{(\mathrm{aq})}$ and $\mathrm{EDTA}_{(\mathrm{aq})}^{4-}$ were quantified independently.

ences, however; the $\mathrm{K}_{\mathrm{d}}$ 's for the metal cations were approximately one log unit lower while those for the anions were in excess of two log units lower than on goethite. These differences were due to the smaller surface area of the Milford sediment, the lower exposed surface area of sorbent $\{[\mathrm{Fe}(\mathrm{III})$ and $\mathrm{Al}(\mathrm{III})$ oxide]\} in the sediment, and the lower intrinsic sorptivity of the natural oxide phases as compared to goethite (Zachara et al., 1995b). The dissociation front of $\mathrm{Fe}(\mathrm{II}) \mathrm{EDTA}_{(\mathrm{aq})}^{2-}$ moved approximately 1.5 units to higher $\mathrm{pH}$ (Fig. 2d) as compared to goethite (Fig. 1d) because of the lower affinity of the Milford sediment for $\mathrm{Fe}_{(\text {aq) }}^{2+}$ (Fig. 2a).

Sorption isotherms of the metal cations on the Milford sediment were analogous, in part, to goethite, with $\mathrm{Fe}_{(\text {aq) }}^{2+}$ being more strongly sorbed than $\mathrm{Co}_{(\mathrm{aq})}^{2+}$ (Fig. 2b). As on goethite, $\mathrm{Co}_{(\mathrm{aq})}^{2+}$ sorption was curvilinear, while $\mathrm{Fe}_{(\mathrm{aq})}^{2+}$ displayed two-part isotherm behavior. Sorption affinity for both cations was much less on the Milford sediment; so much less, in fact that surface sites were not saturated at $\log \left[\mathrm{Me}^{2+}\right]_{\mathrm{aq}}=-3 \mathrm{~mol} / \mathrm{L}$ (Fig. 2b). When plotted in Langmuir format (e.g., $\mathrm{K}_{\mathrm{d}}$ versus $\mathrm{mol} / \mathrm{g}$ ), the isotherms yielded estimated surface saturation values $\left(\mathrm{Fe}_{(\mathrm{aq})}^{2+}=\right.$ $7.20 \times 10^{-7} \mathrm{~mol} / \mathrm{m}^{2} ; \mathrm{Co}_{(\mathrm{aq})}^{2+}=3.53 \times 10^{-7} \mathrm{~mol} / \mathrm{m}^{2}$ ) that were below those of goethite (3.2.1).

\subsection{Sorption Behavior During Bacterial Fe(III) Oxide Reduction}

Masses of goethite $(1.0 \mathrm{~g} / \mathrm{L}$ and $1.5 \mathrm{~g} / \mathrm{L})$ and the Milford sediment $(500 \mathrm{~g} / \mathrm{L})$ were used in the experiments with bacterial inoculation that would yield approximately $75-90 \%$ adsorption of $\mathrm{Co}(\mathrm{II}) \mathrm{EDTA}_{(\mathrm{aq})}^{2-}$ at $\mathrm{pH}$ 6.75. It was presumed that sorption would decrease through bacterial activity, in part because of $\mathrm{Fe}$ (III) reduction and loss of $\mathrm{Fe}(\mathrm{III})$ oxide mass and surface area. Large mass differences were used for the two sorbents because of their difference in sorption affinity (Figs. 1 and 2).

\subsubsection{Fe(II) generation}

Biogenic Fe(II) was strongly sorbed by both goethite and the Milford sediment in presence of $\mathrm{Co}(\mathrm{II}) \mathrm{EDTA}_{(\mathrm{aq})}^{2-}$ (Fig. 3). Sorption, included $\mathrm{Fe}(\mathrm{II})$ adsorbed to the $\mathrm{Fe}(\mathrm{III})$ oxide, complexed to cell materials, and bound to accessory sediment mineral phases. Sorbed $\mathrm{Fe}(\mathrm{II})$ exceeded $\mathrm{Fe}_{(\mathrm{aq})}^{2+}$ concentration by over an order of magnitude. Fe(II) reached asymptotic values after approximately $20 \mathrm{~d}$ for goethite and $75 \mathrm{~d}$ for the Milford. At the asymptote, $2.24 \%$ of the goethite and $10.4 \%$ of the DCB extractable $\mathrm{Fe}(\mathrm{III})$ in the Milford was reduced. We have ob- 


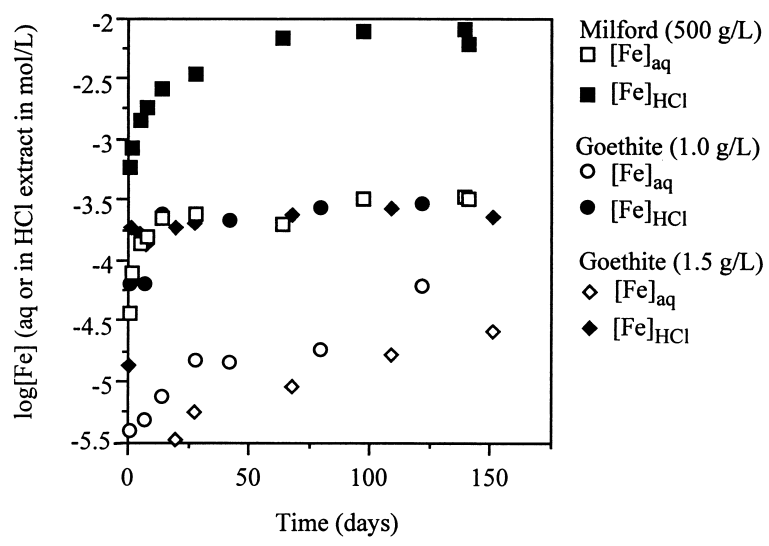

Fig. 3. Concentration of aqueous and total (HCl-extracted) $\mathrm{Fe}(\mathrm{II})$ in bioreduction experiments of goethite and the Milford sediment with $\mathrm{BrY}$ and $\mathrm{Co}(\mathrm{II}) \mathrm{EDTA}^{2-}\left(10^{-5} \mathrm{~mol} / \mathrm{L}\right)$. Solid concentrations as noted. The $\mathrm{HCl}$-extracted $\mathrm{Fe}(\mathrm{II})$ represents sorbed plus aqueous $\mathrm{Fe}(\mathrm{II})$.

served here, and with another Shewanella strain (S. putrefaciens; Zachara et al., 1998), that many natural crystalline $\mathrm{Fe}$ (III) oxides are more reducible than goethite. The total amount of $\mathrm{Fe}(\mathrm{III})$ reduced in the Milford suspension (e.g., $\mathrm{mol} / \mathrm{L} \mathrm{Fe}(\mathrm{II})$ in $\mathrm{HCl}$ extract; Fig. 3) was larger than goethite because of the greater bioavailability of the natural $\mathrm{Fe}(\mathrm{III})$ oxide fraction and the higher mass concentration of reducible $\mathrm{Fe}(\mathrm{III})$ oxide in the suspension $\left[9.15 \times 10^{-2} \mathrm{~mol} / \mathrm{L} \mathrm{Fe}(\mathrm{III})\right.$ in the Milford as compared to $1.13 \times 10^{-2}$ to $1.7 \times 10^{-2} \mathrm{~mol} / \mathrm{L}$ $\mathrm{Fe}(\mathrm{III})$ in the goethite suspensions].

\subsection{2. $C o(I I) E D T A^{2-}$ distribution in goethite/BrY suspensions}

The Fe(II) generated by BrY did not strongly effect the sorption behavior of $\mathrm{Co}(\mathrm{II}) \mathrm{EDTA}_{(\mathrm{aq})}^{2-}$ in goethite suspensions (Fig. 4). While the two experiments with different goethite and organism concentrations differed slightly in magnitude and
Table 4. Measured $\mathrm{pH}$ in sorption/reduction experiments with goethite.

\begin{tabular}{|c|c|c|c|c|c|}
\hline \multicolumn{3}{|c|}{$1.0 \mathrm{~g} / \mathrm{L}$ goethite } & \multicolumn{3}{|c|}{$1.5 \mathrm{~g} / \mathrm{L}$ goethite } \\
\hline $\begin{array}{l}\text { Time } \\
\text { (d) }\end{array}$ & $\begin{array}{c}\text { Without } \\
\text { BrY }\end{array}$ & $\begin{array}{l}\text { With } \\
\text { BrY }\end{array}$ & $\begin{array}{l}\text { Time } \\
\text { (d) }\end{array}$ & $\begin{array}{c}\text { Without } \\
\text { BrY }\end{array}$ & $\begin{array}{l}\text { With } \\
\text { BrY }\end{array}$ \\
\hline 1 & 5.62 & 6.39 & 1 & 5.69 & 6.00 \\
\hline 6.8 & 5.75 & 6.49 & 2 & 5.83 & 5.91 \\
\hline 13.8 & 5.70 & 7.19 & 5 & 5.82 & 5.92 \\
\hline 42.0 & 5.20 & 6.36 & 7.9 & 5.83 & 6.10 \\
\hline 79.9 & 5.66 & 7.59 & 19.7 & 5.64 & 6.50 \\
\hline \multirow{4}{*}{122} & 5.81 & 7.23 & 28.1 & 5.79 & 6.14 \\
\hline & & & 68.1 & 5.26 & 6.20 \\
\hline & & & 109 & 6.29 & 7.39 \\
\hline & & & 151 & 6.03 & 7.20 \\
\hline
\end{tabular}

trend (i.e., Figs. 4a,b), the overall results were similar. That is, the controls (without BrY) evolved to a point where $\mathrm{K}_{\mathrm{d}^{-}}$ $\mathrm{Co}(\mathrm{II})=\mathrm{K}_{\mathrm{d}}$ EDTA $^{4-}=10$. In the biotic experiments, the $\mathrm{K}_{\mathrm{d}}$ 's for both $\mathrm{Co}(\mathrm{II})$ and $\mathrm{EDTA}^{4-}$ were lower than the controls. Also, the $\mathrm{K}_{\mathrm{d}}$-Co(II) increased above the $\mathrm{K}_{\mathrm{d}}$ EDTA $^{4-}$ with time, signifying partial dissociation of the complex according to the following presumed relationship:

$$
\mathrm{Fe}_{(\mathrm{aq})}^{2+}+\mathrm{Co}(\mathrm{II}) \mathrm{EDTA}_{(\mathrm{aq})}^{2-}=\mathrm{Fe}(\mathrm{II}) \mathrm{EDTA}_{(\mathrm{aq})}^{2-}+\mathrm{Co}_{(\mathrm{aq})}^{2+}
$$

Differences between the controls and the biotic experiments resulted from $\mathrm{pH}$, which differed from target values (Table 4). The $\mathrm{pH}$ of the control experiments was lower than targeted $(\mathrm{pH}=5.2-6.0)$, and fell in a range where Co(II)EDTA (aq) $_{2-}^{2-}$ sorption was higher than in the biotic experiments, and where partial dissociation by $\mathrm{Fe}_{(\mathrm{aq})}^{3+}$ occurs (Reaction 3; Fig. 1c). This lower $\mathrm{pH}$ promoted the partial dissociation of the complex in the control experiments $(0-50 \mathrm{~d}$, Figs. 4a,b). In spite of the presence of buffer, the $\mathrm{pH}$ of the biotic experiments increased with time because of proton consumption during bioreduction:
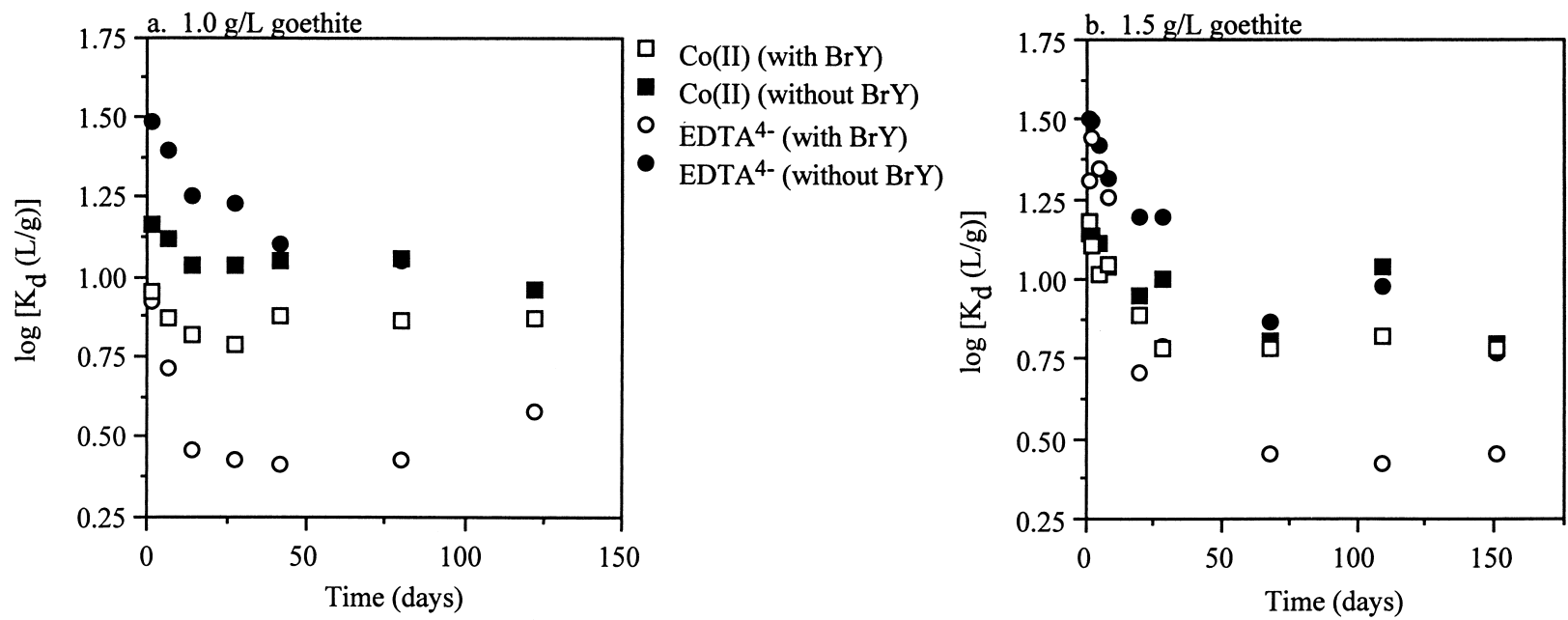

Fig. 4. Solid-liquid distribution of $10^{-5} \mathrm{~mol} / \mathrm{L} \mathrm{Co}(\mathrm{II}) \mathrm{EDTA}^{2-}$ (as $\mathrm{K}_{\mathrm{d}}$ ) in goethite suspensions [a.) $1.0 \mathrm{~g} / \mathrm{L}$ and b.) $1.5 \mathrm{~g} / \mathrm{L}$ ] with e-donor $\left(\mathrm{H}_{2}\right)$ and variable $\mathrm{BrY}$ inoculum in $0.003 \mathrm{~mol} / \mathrm{L} \mathrm{Ca}\left(\mathrm{ClO}_{4}\right)_{2}$. The distribution of $\mathrm{Co}(\mathrm{II}) \mathrm{EDTA}^{2-}$ was determined by dual-label counting of ${ }^{60} \mathrm{Co}$ and ${ }^{14} \mathrm{EDTA}$. Note measured $\mathrm{pH}$ values in Table 4. 
Table 5. Computed aqueous speciation of $\mathrm{Fe}(\mathrm{II}), \mathrm{Co}(\mathrm{II})$, and $\mathrm{EDTA}^{4-}$ in biotic experiment with goethite.

\begin{tabular}{|c|c|c|c|c|c|c|c|c|c|}
\hline $\begin{array}{c}\text { Sorbent } \\
\text { concentration/ } \\
\text { time in days }\end{array}$ & $\mathrm{Fe}(\mathrm{III})_{(\mathrm{aq})-\mathrm{ToT}}{ }^{\mathrm{a}}$ & $\begin{array}{c}\mathrm{Fe}_{(\mathrm{aq})}^{2+} \\
(\mathrm{mol} / \mathrm{L})\end{array}$ & $\mathrm{Fe}(\mathrm{II}) \mathrm{EDTA}_{\text {(aq) }}^{2-}$ & $\mathrm{Co}(\mathrm{II})_{(\mathrm{aq})-\mathrm{TOT}}{ }^{\mathrm{a}}$ & $\begin{array}{c}\mathrm{Co}_{(\mathrm{aq})}^{2+} \\
(\mathrm{mol} / \mathrm{L}) \\
\end{array}$ & \multicolumn{4}{|c|}{$\operatorname{Co}(\mathrm{II}) \mathrm{EDTA}_{(\mathrm{aq})}^{2-} \operatorname{EDTA}_{(\mathrm{aq})-\mathrm{TOT}}{ }^{\mathrm{a}} \mathrm{Fe}(\mathrm{II}) \mathrm{EDTA}_{(\mathrm{aq})}^{2-} \mathrm{Co}(\mathrm{II}) \mathrm{EDTA}_{(\mathrm{aq})}^{2-}$} \\
\hline & & \multicolumn{2}{|c|}{$[\mathrm{C}] / \%$} & & \multicolumn{2}{|c|}{$[\mathrm{C}] / \%$} & & \multicolumn{2}{|c|}{$[\mathrm{C}] / \%$} \\
\hline $1.0 \mathrm{~g} / \mathrm{L} / 79.9 \mathrm{~d}$ & $1.88 \times 10^{-5}$ & $\begin{array}{c}1.71 \times 10^{-5} \\
(91)^{\mathrm{b}}\end{array}$ & $\begin{array}{c}1.48 \times 10^{-6} \\
(7.8)^{\mathrm{b}}\end{array}$ & $1.31 \times 10^{-6}$ & $\begin{array}{c}1.39 \times 10^{-7} \\
(10.6)^{\mathrm{b}}\end{array}$ & $\begin{array}{c}1.17 \times 10^{-6} \\
(89.3)^{\mathrm{b}}\end{array}$ & $2.72 \times 10^{-6}$ & $\begin{array}{c}1.48 \times 10^{-6} \\
(54.2)^{\mathrm{b}}\end{array}$ & $\begin{array}{c}8.12 \times 10^{-7} \\
(43.0)^{\mathrm{b}}\end{array}$ \\
\hline $1.5 \mathrm{~g} / \mathrm{L} / 109 \mathrm{~d}$ & $1.61 \times 10^{-5}$ & $\begin{array}{c}1.48 \times 10^{-5} \\
(92.2)^{\mathrm{b}}\end{array}$ & $\begin{array}{c}1.16 \times 10^{-6} \\
(7.2)^{\mathrm{b}}\end{array}$ & $9.20 \times 10^{-7}$ & $\begin{array}{c}1.07 \times 10^{-7} \\
(11.6)^{\mathrm{b}}\end{array}$ & $\begin{array}{c}8.12 \times 10^{-7} \\
(88.3)^{\mathrm{b}}\end{array}$ & $2.03 \times 10^{-6}$ & $\begin{array}{c}1.16 \times 10^{-6} \\
(57)^{\mathrm{b}}\end{array}$ & $\begin{array}{c}8.12 \times 10^{-7} \\
(40)^{\mathrm{b}}\end{array}$ \\
\hline
\end{tabular}

${ }^{\mathrm{a}} \mathrm{TOT}=$ total component concentration

$\mathrm{b}(\mathrm{l}) \%$ of aqueous component.

$$
\mathrm{FeOOH}_{(\mathrm{s})}+1 / 2 \mathrm{H}_{2(\mathrm{~g})}+2 \mathrm{H}_{(\mathrm{aq})}^{+}=\mathrm{Fe}(\mathrm{II})+2 \mathrm{H}_{2} \mathrm{O}
$$

Higher $\mathrm{pH}$ promoted greater initial stability of the complex, weaker sorption of Co(II)EDTA ${ }_{(\mathrm{aq})}^{2-}$, and stronger sorption of evolved Co(II).

The computed aqueous speciation in the biotic experiments (at $75 \mathrm{~d}$ for $1.0 \mathrm{~g} / \mathrm{L}$ and $109 \mathrm{~d}$ for $1.5 \mathrm{~g} / \mathrm{L}$, Table 5) indicated that $\mathrm{Fe}_{(\mathrm{aq})}^{2+}$ was high enough in concentration to induce some dissociation of Co(II)EDTA $\mathrm{ED}_{(\mathrm{aq})}^{2-}$. The nominal concentration of $\mathrm{Fe}_{(\mathrm{aq})}^{2+}$ was slightly in excess of $\mathrm{Co}(\mathrm{II}) \mathrm{EDTA}_{\text {TOT }}^{2-}(1.6-1.9 \times$ $10^{-5} \mathrm{~mol} / \mathrm{L}$, Table 5), but was greater than $10 \times$ higher than the remaining aqueous concentrations of $\mathrm{Co}$ (II) (form unspecified), Table 5. The calculations indicated that Co(II)EDTA (aq) $_{2-}^{2-}$ was the predominant $\mathrm{Co}(\mathrm{II})$ aqueous species, but that $\mathrm{Fe}(\mathrm{II}) \mathrm{ED}-$ $\mathrm{TA}_{(\mathrm{aq})}^{2-}$ was the predominant EDTA ${ }^{4-}$ species. The computed effects of $\mathrm{Fe}(\mathrm{II})$ on $\mathrm{Co}(\mathrm{II}) \mathrm{EDTA}_{(\mathrm{aq})}^{2-}$ were modest because most of the evolved $\mathrm{Fe}$ (II) was sorbed to the goethite surface (Fig. 3). The total extent of dissociation (i.e., of Co(II)EDTA $\mathrm{EOT}_{\mathrm{TO}}^{2-}$ rather than $\left.\mathrm{Co}(\mathrm{II}) \mathrm{EDTA}_{(\mathrm{aq})}^{2-}\right)$ was not readily computed, however, as most of the chemical mass of both $\mathrm{Co}(\mathrm{II})_{\mathrm{TOT}}$ and $\mathrm{EDTA}_{\mathrm{TOT}}^{4-}$ $(>75 \%)$ was surface associated. It is not known whether the surface speciation of $\mathrm{Co}(\mathrm{II})$ and $\mathrm{EDTA}^{4-}$ matched that in the aqueous phase, but such parity is unlikely. More probable is that the surface ratio of $\mathrm{Co}^{2+}: \mathrm{Co}(\mathrm{II}) \mathrm{EDTA}^{2-}$ exceeded that in solution because: $\mathrm{Co}^{2+}$ is strongly preferred by the surface at this $\mathrm{pH}$; and excess $\mathrm{Fe}_{(\mathrm{aq})}^{2+}$ was present to promote the dissociation of $\mathrm{Co}(\mathrm{II}) \mathrm{EDTA}^{2-}$.

\subsubsection{Co(II)EDTA ${ }^{2-}$ Distribution in Milford/BrY suspensions}

3.3.3.1. Without Malate. The distribution of Co(II)EDTA (aq) $^{2-}$ changed markedly in the Milford sediment after BrY inoculation (Fig. 5a). The inoculated experiment differed from the controls (without BrY) at $<50 \mathrm{~d}$, after which both systems displayed analogous behavior. Because the Milford sediment was not autoclaved (to prevent change in the Fe(III) oxide fraction), we surmised that indigenous $\mathrm{H}_{2}$-utilizing $\mathrm{Fe}$ (III)reducers were present in the sediment that began reducing $\mathrm{Fe}(\mathrm{III})$ after an approximate $50 \mathrm{~d}$ lag period.

The following comments pertain to the inoculated system; they are, however, equally applicable to the uninoculated control after $50 \mathrm{~d}$. Cobalt(II) and EDTA ${ }^{4-}$ showed disparate sorption behavior indicating dissociation of Co(II)EDTA (aq) $^{2-}$ (Fig. 5a). The increase in $\mathrm{K}_{\mathrm{d}} \mathrm{Co}(\mathrm{II})$ (Fig. 5a) between 0 and $25 \mathrm{~d}$ closely paralleled the evolution of $\mathrm{Fe}(\mathrm{II})$ (Fig. 3). The $\mathrm{K}_{\mathrm{d}}$ values for $\operatorname{Co}(\mathrm{II})\left(0.03, \log \mathrm{K}_{\mathrm{d}}=-1.52\right)$ and $\mathrm{EDTA}^{4-}(0.002$, $\left.\log \mathrm{K}_{\mathrm{d}}=-2.69\right)$ after $50 \mathrm{~d}$ approached those for $\mathrm{Co}_{(\mathrm{aq})}^{2+}(\log$ $\mathrm{K}_{\mathrm{d}}=-1.2$, Fig. $\left.2 \mathrm{a}\right)$ and Fe(II)EDTA ${ }_{(\mathrm{aq})}^{2-}\left(\log \mathrm{K}_{\mathrm{d}}=-2.5\right.$, Fig.
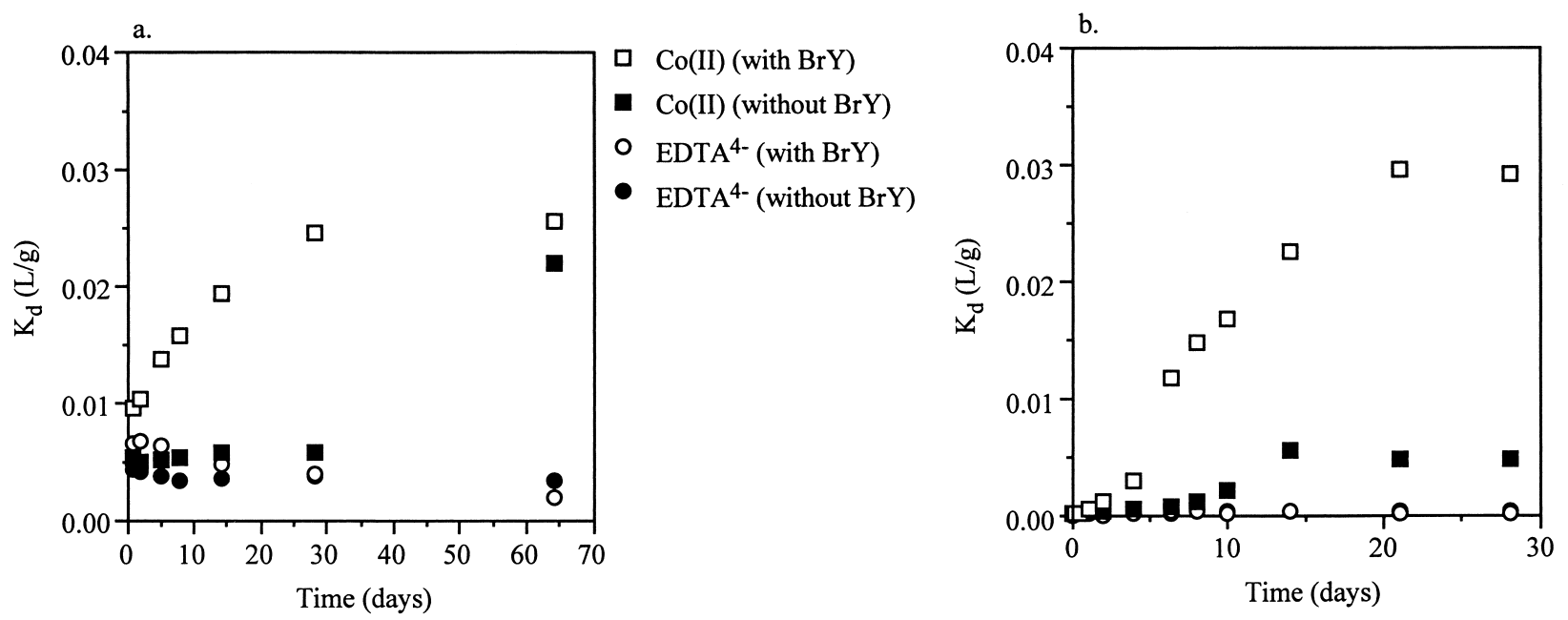

Fig. 5. Solid-liquid distribution of $10^{-5} \mathrm{~mol} / \mathrm{L}$ Co(II)EDTA ${ }^{2-}$ (as $\mathrm{K}_{\mathrm{d}}$ ) in Milford suspensions $(500 \mathrm{~g} / \mathrm{L})$ with e-donor $\left(\mathrm{H}_{2}\right)$ and BrY inoculum. The distribution of Co(II)EDTA ${ }^{2-}$ was determined by dual-label counting of ${ }^{60} \mathrm{Co}$ and ${ }^{14} \mathrm{EDTA}$. a.) without malate. b.) with $30 \mathrm{mM}$ malate. Note measured $\mathrm{pH}$ values for the experiment without malate in Table 6. 
Table 6. Computed distribution of aqueous species in the biotic experiment with the Milford sediment without malate.

\begin{tabular}{|c|c|c|c|c|c|c|c|}
\hline \multirow{3}{*}{$\begin{array}{l}\text { Time } \\
\text { (d) }\end{array}$} & \multirow[b]{3}{*}{$\mathrm{pH}$} & \multicolumn{2}{|c|}{$\mathrm{Co}(\mathrm{II})_{\mathrm{aq}-\mathrm{TOT}^{\mathrm{a}}}$} & \multicolumn{2}{|c|}{$\mathrm{Fe}(\mathrm{II})_{\mathrm{aq}-\text { тот }^{\mathrm{a}}}$} & \multicolumn{2}{|c|}{ EDTA $_{\text {aq-TOT }}^{-}$} \\
\hline & & $\mathrm{Co}_{(\mathrm{aq})}^{2+}$ & Co(II)EDTA $A_{(a q)}^{2+}$ & $\mathrm{Fe}_{(\mathrm{aq})}^{2+}$ & $\mathrm{Fe}(\mathrm{II}) \mathrm{EDTA}_{(\mathrm{aq})}^{2-}$ & $\operatorname{Co}(\mathrm{II}) \mathrm{EDTA}_{(\mathrm{aq})}^{2-}$ & $\mathrm{Fe}(\mathrm{II}) \mathrm{EDTA}_{(\mathrm{aq})}^{2-}$ \\
\hline & & \multicolumn{2}{|c|}{$(\%$ of total $)$} & \multicolumn{2}{|c|}{ (\% of total) } & \multicolumn{2}{|c|}{$(\%$ of total $)$} \\
\hline 1 & 5.85 & 25 & 74.6 & 97 & 2.9 & 53.3 & 45.6 \\
\hline 2 & 5.99 & 37.8 & 62.0 & 98.3 & 1.6 & 43.1 & 56.3 \\
\hline 5 & 6.25 & 45.0 & 54.9 & 98.7 & 1.2 & 28.7 & 70.8 \\
\hline 8 & 6.43 & 43.3 & 56.6 & 98.6 & 1.3 & 23.6 & 76.0 \\
\hline 14 & 6.54 & 47.7 & 52.3 & 98.8 & 1.1 & 16.1 & 83.6 \\
\hline 28 & 6.55 & 44.7 & 55.3 & 98.7 & 1.2 & 12.0 & 87.6 \\
\hline 64 & 6.58 & 30.3 & 69.6 & 97.6 & 2.3 & 10 & 89.6 \\
\hline
\end{tabular}

${ }^{\mathrm{a}} \mathrm{TOT}=$ total component concentration.

2d) measured as individual solutes at $\mathrm{pH}$ 6.5. The computed speciation of the aqueous phase (Table 6) generally affirmed that $\mathrm{Co}(\mathrm{II}) \mathrm{EDTA}_{(\mathrm{aq})}^{2-}$ was being dissociated to yield $\mathrm{Co}_{(\mathrm{aq})}^{2+}$ and $\mathrm{Fe}(\mathrm{II}) \mathrm{EDTA}_{(\mathrm{aq})}^{2-}$. Toward the conclusion of the experiment, $89.6 \%$ of the total $\operatorname{EDTA}_{(\mathrm{aq})}^{4-}$ was computed to exist as $\mathrm{Fe}(\mathrm{II}) \mathrm{EDTA}_{(\mathrm{aq})}^{2-}$. The inequality of $\log \mathrm{K}_{\mathrm{d}^{-}} \mathrm{Co}(\mathrm{II})$ at the end of this experiment $(-1.52)$ with that at comparable $\mathrm{pH}$ in the sorption experiment (Fig. 2a, -1.2) may be attributed to the lingering, but small concentration of $\mathrm{Co}(\mathrm{II}) \mathrm{EDTA}_{(\mathrm{aq})}^{2-}$ (Table 6), or to a competitive effect of sorbed Fe(II) which was approximately at surface saturation.

The effects of BrY on the distribution of Co(II)EDTA ${ }^{2-}$ were greater for the Milford sediment than for goethite because the resulting $\mathrm{Fe}_{(\mathrm{aq})}^{2+}$ concentration was larger (Fig. 3) in the sediment. The larger $\mathrm{Fe}_{(\mathrm{aq})}^{2+}$ concentration resulted from two factors:

1. Fe(III) oxides in the Milford sediment were more extensively reduced than was goethite; and

2. The Milford sediment did not sorb Fe(II) as strongly as goethite.

3.3.3.2. With Malate. The presence of $0.030 \mathrm{~mol} / \mathrm{L}$ malate, added as an assimilatable carbon source, suppressed the initial sorption of $\mathrm{Co}(\mathrm{II}) \mathrm{EDTA}_{(\mathrm{aq})}^{2-}$ (Fig. 5b). The supression was attributed to an anion competition effect from malate, as the sorption of Co(II)EDTA $\mathrm{Eaq}_{(\mathrm{a})}^{2-}$ is weak and decreases with increasing electrolyte concentration (Girvin et al., 1993; Zachara et al., 1995b; and unpublished data). The $\mathrm{KH}_{2} \mathrm{PO}_{4}\left(5 \times 10^{-5} \mathrm{~mol} / \mathrm{L}\right)$ present in the media of this one experiment may also have acted

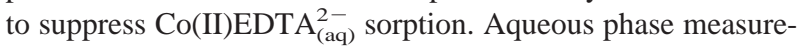
ments (not shown) indicated that most of the $\mathrm{PO}_{4}$ was sorbed. EDTA $^{4-}$ sorption remained low throughout the experiment implying that the sorption of Fe(II)EDTA ${ }^{2-}$ was suppressed as well.

The $\mathrm{K}_{\mathrm{d}}-\mathrm{Co}(\mathrm{II})$, however, increased with time (Fig. 5b) paralleling the reduction of $\mathrm{Fe}$ (III) and the release of $\mathrm{Fe}_{(\mathrm{aq})}^{2+}$ (data not shown). After approximately $20 \mathrm{~d}, \mathrm{~K}_{\mathrm{d}}-\mathrm{Co}$ (II) reached a final value $\left(0.03, \log \mathrm{K}_{\mathrm{d}}=-1.52\right)$ close to that in the experiment without malate (Fig. 5a). The computed aqueous speciation at that point (Table 7), indicated that close to $67.3 \%$ of the total $\mathrm{Co}(\mathrm{II}) \mathrm{EDTA}^{2-}$ concentration had been dissociated to $\mathrm{Co}$ (II) and $\mathrm{Fe}(\mathrm{II}) \mathrm{EDTA}_{(\mathrm{aq})}^{2-}$. The sorption of free $\mathrm{Co}^{2+}$ led to the noted increase in $\mathrm{K}_{\mathrm{d}}-\mathrm{Co}(\mathrm{II})$. As in the preceding experiment, the lack of parity in $\log \mathrm{K}_{\mathrm{d}}$ - $\mathrm{Co}$ (II) at $20 \mathrm{~d}(-1.52)$ versus that at $\mathrm{pH} 7$ in Fig. 2a $(-0.5)$ may have resulted from the effects of aqueous complexation (by both $\mathrm{EDTA}^{4-}$ and malate) and/or the competitive effects of sorbed Fe(II).

\subsubsection{Co(II)EDTA ${ }^{2-}$ sorption on the biotically reduced Milford sediment}

Approximately $10-20 \%$ of the DCB-extractable Fe(III)-oxides in the Milford sediment were reduced during the biotic experiments described above. This amount of reduction, however, had minimal impact on the sorptivity of Co(II)EDTA $\mathrm{EDaq}_{\text {(a) }}^{2-}$ to the sediment that had been washed with $\mathrm{Ca}\left(\mathrm{ClO}_{4}\right)_{2}$ to displace sorbed $\mathrm{Fe}(\mathrm{II})$ (Fig. 6.). $\mathrm{Fe}(\mathrm{III})$ and $\mathrm{Al}(\mathrm{III})$ oxides are the primary sorbents for $\mathrm{Co}(\mathrm{II}) \mathrm{EDTA}_{(\mathrm{aq})}^{2-}$ in the Milford sediment (Zachara et al., 1995b). The approximate parity in sorption of the original and reduced material suggests that either the reactive surface area of $\mathrm{Fe}$ (III) oxide fraction was conserved during reduction or that a commensurate amount of $\mathrm{Al}(\mathrm{III})$ oxides were exposed. Chemical extractions of soils and subsurface sediments have shown that $\mathrm{Fe}$ (III) oxide removal need not lead to a decrease in metal ion sorption if $\mathrm{Al}$ oxides are also present (Zachara et al., 1992; Zachara et al., 1994).

\subsection{Abiotic Simulation by $\mathrm{Fe}_{(\mathrm{aq})}^{2+}$ Titration}

Ferrous iron was metered into Co(II)EDTA ${ }^{2-}$ suspensions with goethite and the Milford sediment to abiotically simulate the effect of $\mathrm{Fe}(\mathrm{II})$ evolution on $\mathrm{Co}(\mathrm{II}) \mathrm{EDTA}_{(\mathrm{aq})}^{2-}$ stability and sorption. Note that surface reactions of $\mathrm{Fe}_{(\mathrm{aq})}^{2+}$ had a significant impact on solution $\mathrm{pH}$ (Table 8 and 9) and these changes must be considered along with the $\mathrm{pH}$ sorption trends in Figs. 1 and 2 (e.g., of $\mathrm{K}_{\mathrm{d}}-\mathrm{Co}$ (II) and $\mathrm{K}_{\mathrm{d}^{-}}$EDTA $^{4-}$ ) to understand the results that follow.

\subsubsection{Goethite}

The addition of increasing concentrations of $\mathrm{Fe}_{(\mathrm{aq})}^{2+}$ to goethite suspensions had differing impacts on the distribution of $\mathrm{Co}(\mathrm{II}) \mathrm{EDTA}_{\text {(aq) }}^{2-}$ depending on initial pH (Fig. 7). At lower $\mathrm{pH}$ (5.5-4.3) where neither $\mathrm{Fe}_{(\mathrm{aq})}^{2+}$ or $\mathrm{Co}_{(\mathrm{aq})}^{2+}$ were strongly sorbed (Fig. 1), increasing $\mathrm{Fe}_{(\text {aq) }}^{2+}$ concentrations led to a systematic decrease in $\mathrm{K}_{\mathrm{d}}-\mathrm{Co}$ (II) after a threshold value was achieved. The behavior was consistent with $\mathrm{Fe}^{2+}$ saturation of the goethite surface followed by the $\mathrm{Fe}_{(\mathrm{aq})}^{2+}$ induced dissociation of $\mathrm{Co}(\mathrm{II}) \mathrm{EDTA}^{2-}$ (Reaction 7) to a mixture of $\mathrm{Co}^{2+}, \mathrm{Fe}^{2+}$, 


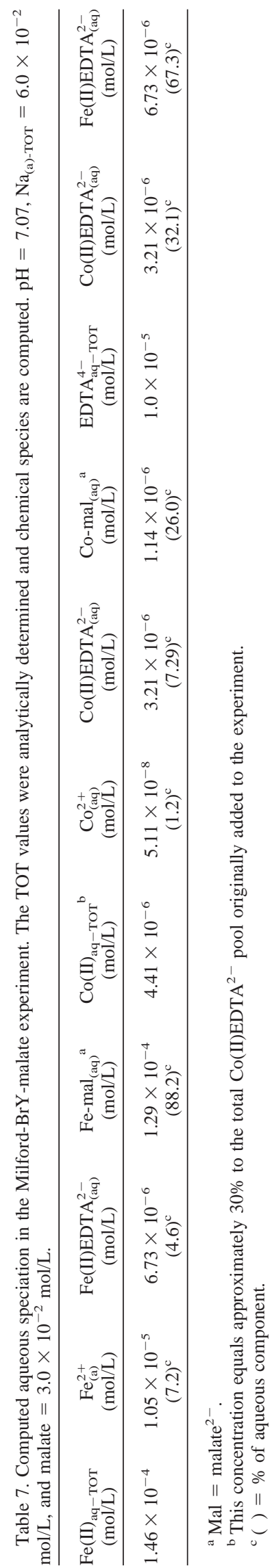




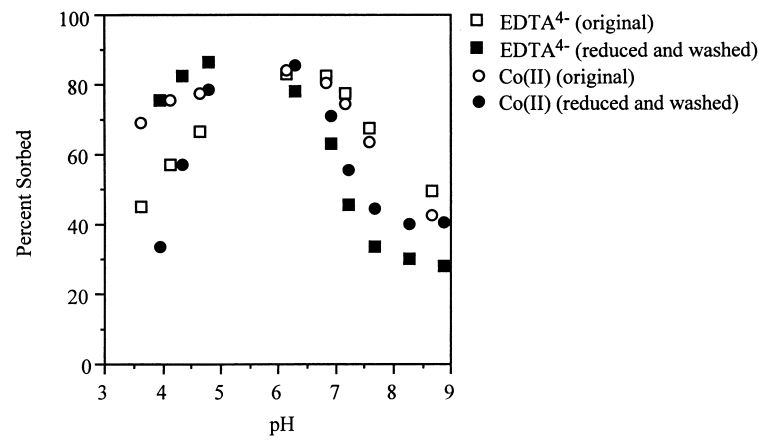

Fig. 6. Percent sorption of $10^{-5} \mathrm{~mol} / \mathrm{L} \mathrm{Co}(\mathrm{II}) \mathrm{EDTA}^{2-}$ on the natural and bioreduced Milford sediment. The distribution of Co(II)EDTA ${ }^{2-}$ was determined by dual-label counting of ${ }^{60} \mathrm{Co}$ and ${ }^{14} \mathrm{EDTA}$. The bioreduced sediment was washed free of sorbed $\mathrm{Fe}(\mathrm{II})$ with $\mathrm{Ca}\left(\mathrm{ClO}_{4}\right)_{2}$.

Co(II)EDTA ${ }^{2-}$, and Fe(II)EDTA ${ }^{2-}$. Aqueous speciation calculations like those in Tables 3, 5, 6, and 7 demonstrated this effect (not shown). The general constancy of $\mathrm{K}_{\mathrm{d}}-\mathrm{EDTA}^{4-}$ as the initial concentration of $\mathrm{Fe}_{(\mathrm{aq})}^{2+}$ was increased reflected the rather high and comparable sorptivity of both $\mathrm{Co}(\mathrm{II}) \mathrm{EDTA}_{\text {(aq) }}^{2-}$ and $\mathrm{Fe}(\mathrm{II}) \mathrm{EDTA}_{(\mathrm{aq})}^{2-}$ at these pH's (Fig. 1).

At higher $\mathrm{pH}$ (6.83-5.85), Co(II)EDTA (aq) $^{2-}$ was less strongly sorbed, but $\mathrm{Fe}_{(\mathrm{aq})}^{2-}$ was more strongly sorbed than at lower $\mathrm{pH}$. The slight tendency for both $\mathrm{K}_{\mathrm{d}} \mathrm{Co}$ (II) and $\mathrm{K}_{\mathrm{d}}-\mathrm{EDTA}^{4-}$ to increase with increasing $\mathrm{Fe}_{(\mathrm{aq})}^{2+}$ may result from enhanced sorption of the intact complex promoted by adsorbed positive charge density $\left(\mathrm{SO}-\mathrm{Fe}^{+}\right.$, reaction 1$)$. Surface saturation occurred above an initial concentration of $10^{-3.5} \mathrm{~mol} / \mathrm{L}$, allowing $\mathrm{Fe}_{(\mathrm{aq})}^{2+}$ to increase. This, inturn, promoted complex dissociation and the decrease of $\mathrm{K}_{\mathrm{d}}-\mathrm{Co}(\mathrm{II})$ consistent with the sorption data in Figure 1. The relationship between $\mathrm{pH}$, final $\mathrm{Fe}_{(\text {aq) }}^{2+}$, and the apparent dissociation of Co(II)EDTA ${ }^{2-}$ is summarized for the two experiments with different $\mathrm{pH}$ values in Table 8. Dissociation extent correlated with the appearance and concentration of $\mathrm{Fe}_{(\mathrm{aq})}^{2+}$.

Table 8. Ferrous iron concentrations in $\mathrm{Fe}_{(\mathrm{aq})}^{2+}$ metering experiment with goethite.

\begin{tabular}{cccc}
\hline $\begin{array}{c}\text { Initial Fe }_{(\text {aq }}^{2+} \\
(\mathrm{mol} / \mathrm{L})\end{array}$ & $\begin{array}{c}\mathrm{Final} \mathrm{Fe}_{(\mathrm{aq})}^{2+} \\
(\mathrm{mol} / \mathrm{L})\end{array}$ & Final $\mathrm{pH}$ & Dissociation $^{\mathrm{a}}$ \\
\hline $10^{-6.0}$ & $\mathrm{DL}$ & 5.45 & $\mathrm{~N}$ \\
$10^{-5.5}$ & $\mathrm{DL}$ & 5.33 & $\mathrm{~N}$ \\
$10^{-5.0}$ & $\mathrm{DL}$ & 5.06 & $\mathrm{~N}$ \\
$10^{-4.5}$ & $10^{-5.85}$ & 4.74 & $\mathrm{Y}$ \\
$10^{-4.0}$ & $10^{-4.20}$ & 4.55 & $\mathrm{Y}$ \\
$10^{-3.5}$ & $10^{-3.58}$ & 4.42 & $\mathrm{Y}$ \\
$10^{-3.0}$ & $10^{-3.06}$ & 4.31 & $\mathrm{Y}$ \\
$10^{-6.0}$ & $\mathrm{DL}$ & 6.83 & $\mathrm{~N}$ \\
$10^{-5.5}$ & $\mathrm{DL}$ & 6.84 & $\mathrm{~N}$ \\
$10^{-5.0}$ & $\mathrm{DL}$ & 6.83 & $\mathrm{~N}$ \\
$10^{-4.5}$ & $\mathrm{DL}$ & 6.83 & $\mathrm{~N}$ \\
$10^{-4.0}$ & $\mathrm{DL}$ & 6.81 & $\mathrm{~N}$ \\
$10^{-3.5}$ & $10^{-5.7}$ & 6.70 & $\mathrm{~N}$ \\
$10^{-3.0}$ & $10^{-3.25}$ & 6.65 & $\mathrm{Y}$ \\
\hline
\end{tabular}

$\mathrm{DL}=$ below the analytical detection limit $10^{-6.25} \mathrm{~mol} / \mathrm{L}$.

${ }^{a}$ As implied by difference in $\mathrm{K}_{\mathrm{d}-} \mathrm{Co}(\mathrm{II})$ versus $\mathrm{K}_{\mathrm{d}-} \mathrm{EDTA}^{4-}$.
Table 9. Ferrous iron concentrations in $\mathrm{Fe}_{(\mathrm{aq})}^{2+}$ metering experiment with Milford sediment.

\begin{tabular}{cccc}
$\begin{array}{c}\text { Initial Fe }_{(\text {aq })}^{2+} \\
(\mathrm{mol} / \mathrm{L})\end{array}$ & $\begin{array}{c}\mathrm{Final} \mathrm{Fe}_{(\text {aq })}^{2+} \\
(\mathrm{mol} / \mathrm{L})\end{array}$ & Final $\mathrm{pH}$ & Dissociation $^{\mathrm{a}}$ \\
\hline $10^{-6.0}$ & $\mathrm{DL}$ & 6.13 & $\mathrm{~N}$ \\
$10^{-5.5}$ & $\mathrm{DL}$ & 6.14 & $\mathrm{~N}$ \\
$10^{-5.0}$ & $\mathrm{DL}$ & 6.21 & $\mathrm{~N}$ \\
$10^{-4.5}$ & $\mathrm{DL}$ & 6.19 & $\mathrm{~N}$ \\
$10^{-4.0}$ & $\mathrm{DL}$ & 6.08 & $\mathrm{~N}$ \\
$10^{-3.5}$ & $10^{-4.66}$ & 5.63 & $\mathrm{Y}$ \\
$10^{-3.0}$ & $10^{-3.54}$ & 5.42 & $\mathrm{Y}$ \\
$10^{-6.0}$ & $\mathrm{DL}$ & 6.79 & $\mathrm{~N}$ \\
$10^{-5.5}$ & $\mathrm{DL}$ & 6.81 & $\mathrm{~N}$ \\
$10^{-5.0}$ & $\mathrm{DL}$ & 6.83 & $\mathrm{~N}$ \\
$10^{-4.5}$ & $\mathrm{DL}$ & 6.81 & $\mathrm{~N}$ \\
$10^{-4.0}$ & $\mathrm{DL}$ & 6.81 & $\mathrm{~N}$ \\
$10^{-3.5}$ & $10^{-5.75}$ & 6.75 & $\mathrm{Y}$ \\
$10^{-3.0}$ & $10^{-4.30}$ & 6.53 & $\mathrm{Y}$ \\
\hline
\end{tabular}

$\mathrm{DL}=$ below the analytical detection limit of $10^{-6.25} \mathrm{~mol} / \mathrm{L}$.

${ }^{a}$ As implied by difference in $\mathrm{K}_{\mathrm{d}}-\mathrm{Co}(\mathrm{II})$ versus $\mathrm{K}_{\mathrm{d}}$-EDTA ${ }^{4-}$.

\subsubsection{Milford sediment}

The sorption behavior of Co(II)EDTA ${ }^{2-}$ in the Milford suspension with $\mathrm{Fe}_{(\mathrm{aq})}^{2+}$ titration (Fig. 8) was, in part, analogous
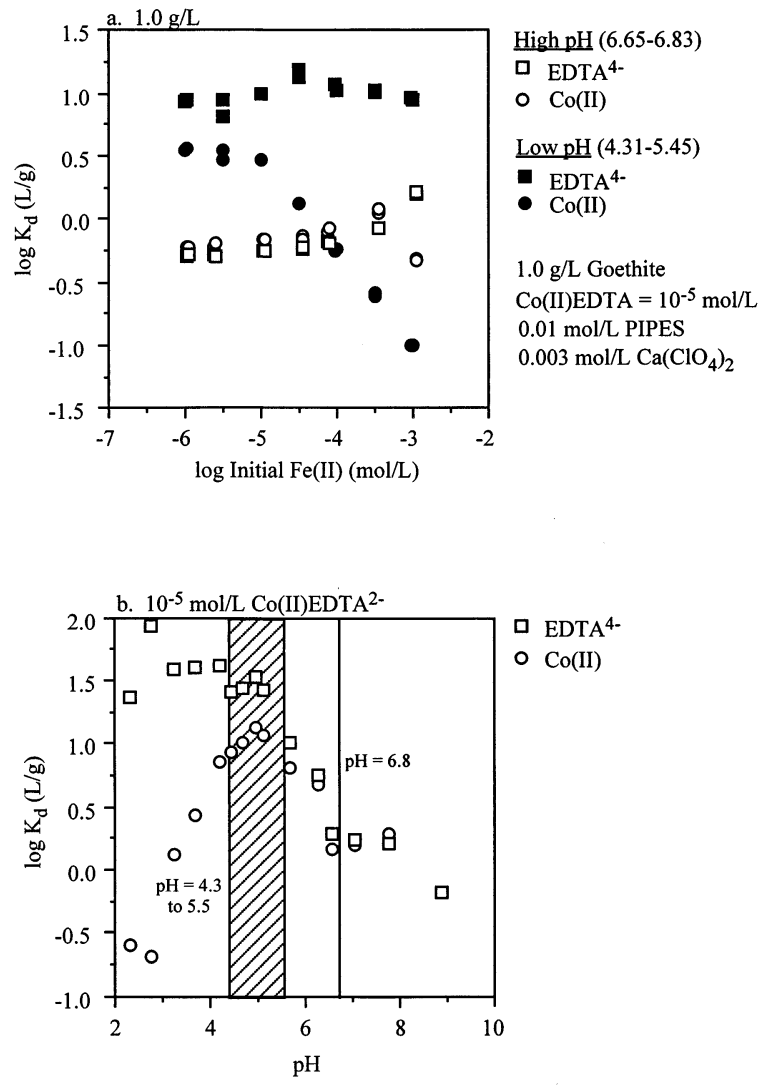

Fig. 7. a.) Influence of $\mathrm{Fe}_{(\text {aq) }}^{2+}$ addition on the distribution of $\mathrm{Co}(\mathrm{I}-$ I)EDTA ${ }^{2-}$ in goethite suspensions at two different initial $\mathrm{pH}$ values. Final $\mathrm{pH}$ values are noted in Table 8. b.) $\mathrm{K}_{\mathrm{d}}$ 's for $\mathrm{Co}(\mathrm{II})$ and $\mathrm{EDTA}^{4-}$ in $\mathrm{Co}(\mathrm{II}) \mathrm{EDTA}^{2-}$ from Fig. 2 with the $\mathrm{pH}$ range for the experiments in a.) noted. 

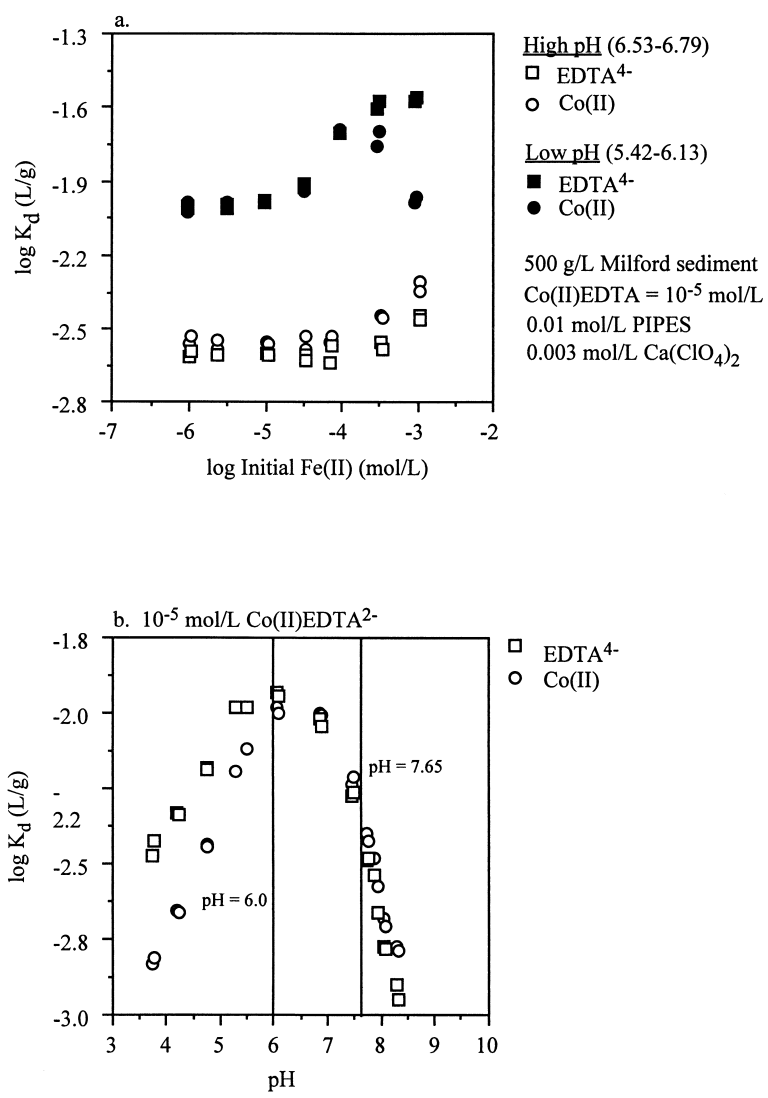

Fig. 8. a.) Influence of $\mathrm{Fe}_{(\mathrm{aq})}^{2+}$ addition on the distribution of Co(II)EDTA ${ }^{2-}$ in Milford sediment suspensions at two different $\mathrm{pH}$ values. The distribution of Co(II)EDTA ${ }^{2-}$ was determined by duallabel counting of ${ }^{60} \mathrm{Co}$ and ${ }^{14} \mathrm{EDTA}$. b.) $\mathrm{K}_{\mathrm{d}}$ 's for $\mathrm{Co}(\mathrm{II})$ and $\mathrm{EDTA}^{4-}$ in $\mathrm{Co}(\mathrm{II}) \mathrm{EDTA}^{2-}$ with the $\mathrm{pH}$ range for the experiments in a.) noted.

to that of goethite (Fig. 7). Differences were observed, however, that resulted from the solid-to-solution ratio (500 g/L) and $\mathrm{pH}$ of the Milford suspensions that strongly affected the extent of $\mathrm{Fe}_{(\mathrm{aq})}^{2+}$ sorption and its final aqueous concentration. The similarity in the Milford data between $\mathrm{pH}=6.13$ to 5.42 with that of goethite between $\mathrm{pH}=6.83$ to 5.85 implied that the same reaction suite was operative, including the apparent enhancement of $\mathrm{Co}(\mathrm{II}) \mathrm{EDTA}^{2-}$ sorption by sorbed $\mathrm{Fe}_{(\mathrm{aq})}^{2+}$. As noted for goethite, the observance of dissociation and its extent correlated with the appearance and concentration of $\mathrm{Fe}_{(\mathrm{aq})}^{2+}$ (Table 9).

\section{DISCUSSION}

\subsection{The Sorbing Surface in Bioreduced Materials}

Recently, we showed that siderite $\left(\mathrm{FeCO}_{3}\right)$ and vivianite $\left[\mathrm{Fe}_{3}\left(\mathrm{PO}_{4}\right)_{2} \cdot 8 \mathrm{H}_{2} \mathrm{O}\right]$ were biomineralization products resulting from the reduction of crystalline $\mathrm{Fe}(\mathrm{III})$ oxides by DIRB (Zachara et al., 1998). The formation of vivianite requires $\mathrm{P}$ addition to the media (often in $\mathrm{mM}$ concentration) while siderite formation is promoted by bicarbonate typically included to buffer $\mathrm{pH}$ in the medium. $\mathrm{P}$ was excluded from all experiments herein except one (Fig. 5b) and $\mathrm{HCO}_{3}$ was not used as a buffer. Therefore, significant carbonate or phosphate biomin-

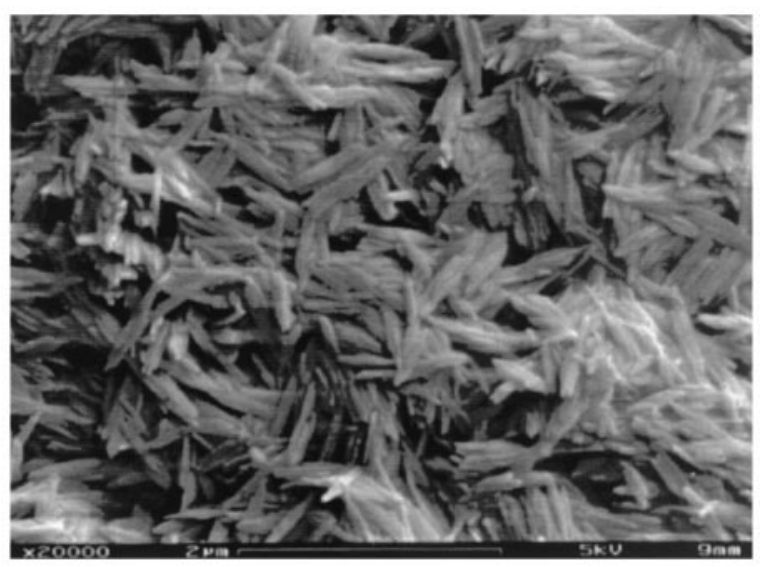

Fig. 9. Scanning electron micrograph of the goethite used in this study after bioreduction by Shewanella putrefaciens, strain CN-32 in pipes buffer. 2 um scale bar as noted.

eralization was not expected. X-ray diffraction analyses of this same goethite and Milford sediment that were bioreduced by Shewanella putrefaciens strain $\mathrm{CN}-32$ under culture conditions identical to those used here showed no discernable biomineralization products. In PIPES buffer, the bioreduced goethite appeared identical to the starting goethite (Fig. 9). When present, biomineralization products are generally clearly visible by SEM (Fredrickson et al., 1998; Zachara et al., 1999) and were not observed here.

The asymptotic values of the sorbed $\mathrm{Fe}(\mathrm{II})$ concentrations $[\mathrm{Fe}(\mathrm{II})-\mathrm{HCl}]$ in both the bioreduced goethite $\left(10^{-3.6} \mathrm{~mol} / \mathrm{L}\right)$ and Milford $\left(10^{-2.15} \mathrm{~mol} / \mathrm{L}\right)$ suspensions (Fig. 3) when normalized to initial surface area (Fig. 10) were close to one another and were within a factor of 1.5-2.75 times the $\mathrm{Fe}^{2+}$ sorption capacities estimated from the isotherms (3.2). These data support speculation that, under the specific media and substrate conditions used here, that saturation of adsorbing surfaces with $\mathrm{Fe}$ (II) has controlled and limited the bioreduction of the $\mathrm{Fe}(\mathrm{III})$ oxides by $S$. alga. The apparent excess saturation of the goethite and Milford surfaces may result from:

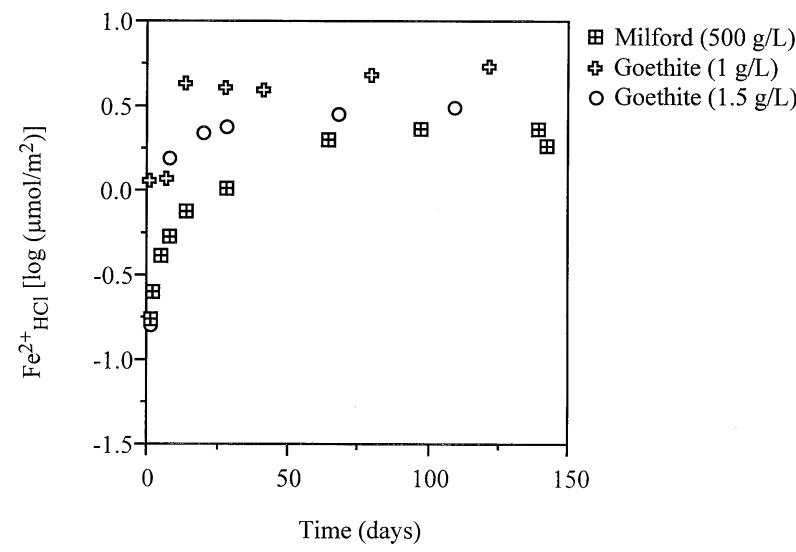

Fig. 10. The sorbed concentration of Fe(II) (in $\mu \mathrm{mol} / \mathrm{m}^{2}$ ) in suspensions of goethite and the Milford sediment with e-donor $\left(\mathrm{H}_{2}\right)$ and $\mathrm{BrY}$ inoculum. Data transformed from Fig. 3. 


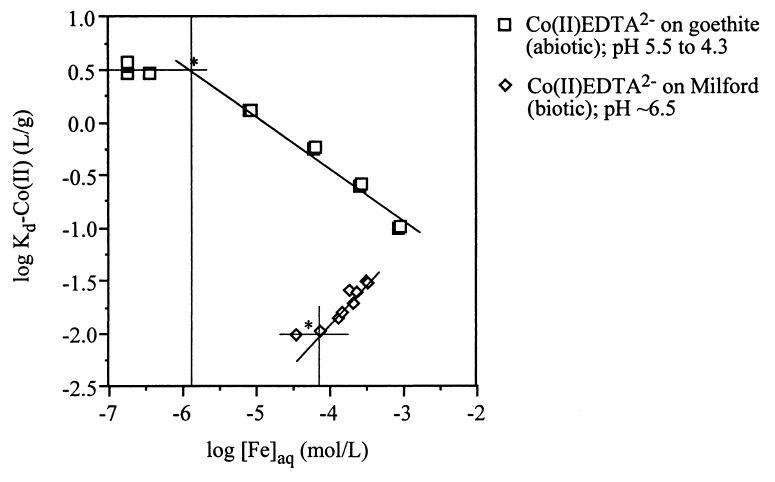

Fig. 11. Influence of $\mathrm{Fe}_{(\mathrm{aq})}^{2+}$ on the $\mathrm{K}_{\mathrm{d}}$ of $\mathrm{Co}(\mathrm{II})$ associated with Co(II)EDTA ${ }^{2-}$. Selected data from an abiotic experiment with goethite (Fig. 7a) and a biotic experiment (Fig. 5a) with the Milford sediment. For the abiotic experiment, the $\mathrm{Fe}_{(\text {aq }}^{2+}$ is the final concentration remaining after spiking with a larger initial value. The noted responses for both data sets are less than the anticipated 1:1 relationship.

1. $\mathrm{pH}$ differences between the isotherm and bioreduction experiments;

2. Biosorption of Fe(II) to microorganism surfaces or cell fragments (e.g., Urrutia et al., 1998);

3. An increase in effective surface area accompanying dissolution; or

4. Deep structural bioreduction.

Regardless of mechanism, the sorbing surface presented to $\mathrm{Co}$ (II)EDTA ${ }^{2-}$ in the intermediate to latter stages of the bioreduction experiments appears to be saturated with $\mathrm{Fe}(\mathrm{II})$.

\subsection{Impacts of $\mathrm{Fe}(\mathrm{III})$ Reduction on Co(II)EDTA ${ }^{2-}$ Chemistry}

The impacts of biologic reduction on the solid-liquid distribution of Co(II)EDTA ${ }^{2-}$ may be explained by separately considering the effects of aqueous and sorbed Fe(II).

\subsubsection{Effects of $\mathrm{Fe}_{(a q)}^{2+}$}

The most important impact of DIRB-Fe(III) oxide reduction on the sorption and stability $\mathrm{Co}(\mathrm{II}) \mathrm{EDTA}^{2-}$ was through the liberation of $\mathrm{Fe}_{(\mathrm{aq})}^{2+}$. Although $\mathrm{Fe}(\mathrm{II})$ was generated in $\mathrm{mM}$ concentration, most of this remained in a sorbed state and had little discernable impact on Co(II)EDTA ${ }^{2-}$ speciation or sorption. Goethite, in particular, strongly held $\mathrm{Fe}(\mathrm{II})$; and for this reason the impacts of bioreduction on Co(II)EDTA ${ }^{2-}$ sorption were minimal. However, increasing amounts of $\mathrm{Fe}_{(\mathrm{aq})}^{2+}$ were observed with time during bioreduction as the solids approached sorption saturation. The effect of $\mathrm{Fe}_{(\mathrm{aq})}^{2+}$ was to induce dissociation of $\mathrm{Co}(\mathrm{II}) \mathrm{EDTA}_{(\mathrm{aq})}^{2-}$ via reactions 7 and 1.

Significant dissociation was only noted when $\mathrm{Fe}_{(\mathrm{aq})}^{2+}>$ $\mathrm{Co}(\mathrm{II}) \mathrm{EDTA}_{\text {(aq) }}^{2-}$ because of the difference in the stability constants of Co(II)EDTA (aq) $^{2-}$ and Fe(II)EDTA (aq) $^{2-}$ (Table 2). However, because the sorption of Co(II)EDTA ${ }^{2-}$ and $\mathrm{Co}^{2+}$ varied with both $\mathrm{pH}$ and the sorbent (Figs. 1 and 2), a common threshold $\mathrm{Fe}_{(\mathrm{aq})}^{2+}$ concentration that induced dissociation was not defined. This is shown in Figure 11 where the apparent dissociation of $\mathrm{Co}(\mathrm{II}) \mathrm{EDTA}_{(\mathrm{aq})}^{2-}$ was implied from the relationship of $\mathrm{K}_{\mathrm{d}}-\mathrm{Co}(\mathrm{II})$ to $\mathrm{Fe}_{(\mathrm{aq})}^{2+}$. Dissociation commenced at approximately

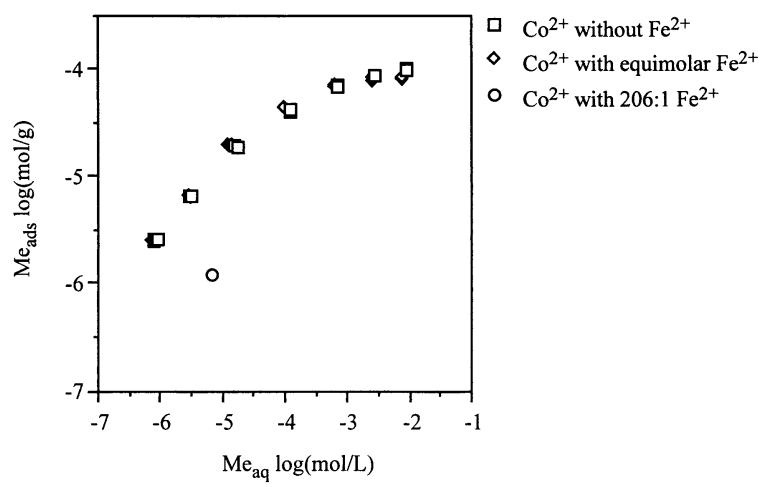

Fig. 12. Competitive sorption isotherm of $\mathrm{Co}_{(\mathrm{aq})}^{2+}$ and $\mathrm{Fe}_{(\mathrm{aq})}^{2+}$ on goethite at $\mathrm{pH} 6.5 \mathrm{in} 0.003 \mathrm{~mol} / \mathrm{L} \mathrm{Ca}\left(\mathrm{ClO}_{4}\right)_{2}$. Conditions were as noted. At the Fe(II): Co ratio of $206: 1$, only a single measurement was obtained.

$10^{-6} \mathrm{~mol} / \mathrm{L} \mathrm{Fe}_{(\mathrm{aq})}^{2+}$ in goethite suspension and $10^{-4} \mathrm{~mol} / \mathrm{L} \mathrm{Fe}_{(\text {aq) }}^{2+}$ in Milford suspension (see asterisks in Fig. 11). The net effect of dissociation was to change the $\mathrm{K}_{\mathrm{d}}-\mathrm{Co}(\mathrm{II})$, which either increased or decreased depending on $\mathrm{pH}$ (Fig. 11) and the sorbate preference of the sorbent. Generally, a linear or curvilinear (if $\mathrm{pH}$ varied) dependence of $\mathrm{K}_{\mathrm{d}}-\mathrm{Co}$ (II) on $\mathrm{Fe}_{(\mathrm{aq})}^{2+}$ was observed above the threshold $\mathrm{Fe}_{(\text {aq) }}^{2+}$ concentration (Fig. 11). In contrast, the $\mathrm{K}_{\mathrm{d}}$-EDTA ${ }^{2-}$ was little changed by dissociation because the sorptivity of $\mathrm{Co}(\mathrm{II}) \mathrm{EDTA}_{(\mathrm{aq})}^{2-}$ and $\mathrm{Fe}(\mathrm{II}) \mathrm{EDTA}_{(\mathrm{aq})}^{2-}$ were similar at intermediate $\mathrm{pH}$.

Although this study was not designed to evaluate the kinetics of $\mathrm{Co}(\mathrm{II})-\mathrm{Fe}(\mathrm{II})$ exchange in the $\mathrm{EDTA}^{4-}$ complex, the experimental data suggests that the exchange rate was rapid, on the scale of hours at least. Consistent with our data, Xue et al. (1995) observed that the exchange rate of Fe(III)EDTA ${ }^{-}$was slow $\left(t_{1} / 2 \approx 20 \mathrm{~d}\right)$, but the rate for divalent metals (i.e., $\mathrm{Ca}^{2+}$ and $\mathrm{Zn}^{2+}$ ) was far more rapid. They further speculated that the exchange rate of $\mathrm{Fe}(\mathrm{II}) \mathrm{in} /$ with $\mathrm{EDTA}^{4-}$ complexes under anoxic conditions would also be rapid and comparable to other divalent metals.

\subsubsection{Effects of surface $\mathrm{Fe}(I I)$}

There was surprisingly little discernable impact of sorbed $\mathrm{Fe}$ (II) on the chemistry of $\mathrm{Co}(\mathrm{II}) \mathrm{EDTA}^{2-}$. It was noted in several instances that the measured $\mathrm{K}_{\mathrm{d}}$ - $\mathrm{Co}$ (II) [for $\mathrm{Co}(\mathrm{II}) \mathrm{EDTA}^{2-}$ ] in biotic or abiotic systems where full dissociation of $\mathrm{Co}$ (II)EDTA ${ }^{2-}$ by $\mathrm{Fe}_{(\mathrm{aq})}^{2+}$ was computed, were lower by factors of 1.5 to 3 than $\mathrm{K}_{\mathrm{d}}$ 's measured for $\mathrm{Co}^{2+}$ at comparable $\mathrm{pH}$ on non-reduced sediments. While it may be surmised that bioreduction may have reduced the sorption of $\operatorname{Co}(\mathrm{II}) \mathrm{EDTA}_{(\mathrm{aq})}^{2-}$ by sorbent depletion or transformation, Figure 6 refutes that possibility. More likely is that $\mathrm{Fe}_{(\text {aq) }}^{2+}$ and $\mathrm{Co}_{(\text {aq) }}^{2+}$ compete for cation sorption sites on the oxide, and that the high surface saturation of $\mathrm{Fe}(\mathrm{II})$ blocks and reduces $\mathrm{Co}_{(\mathrm{aq})}^{2+}$ sorption. A limited competitive isotherm was measured for $\mathrm{Co}_{(\mathrm{aq})}^{2+}$ in presence of sorbed $\mathrm{Fe}_{(\mathrm{aq})}^{2+}$ on goethite (Fig. 12) to test this hypothesis. Experimental procedures were used that were identical to those used for the isotherms in Figure 1, except that $\mathrm{Fe}_{(\mathrm{aq})}^{2+}$ was equilibrated with the goethite for $2 \mathrm{~h}$ prior to $\mathrm{Co}_{(\mathrm{aq})}^{2+}$ addition. At equimolar concentration $\mathrm{Fe}_{(\mathrm{aq})}^{2+}$ had no impact on 
a.

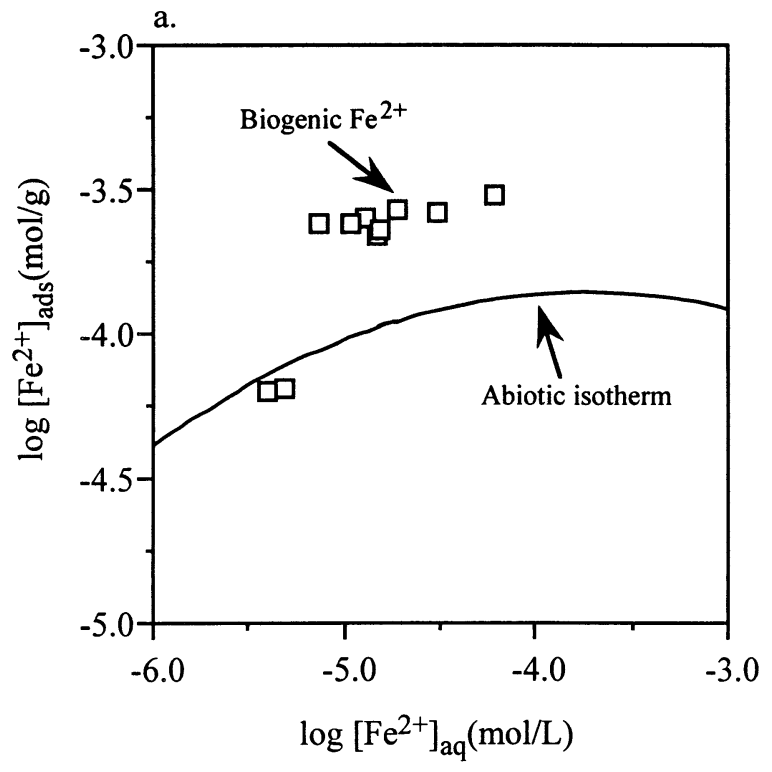

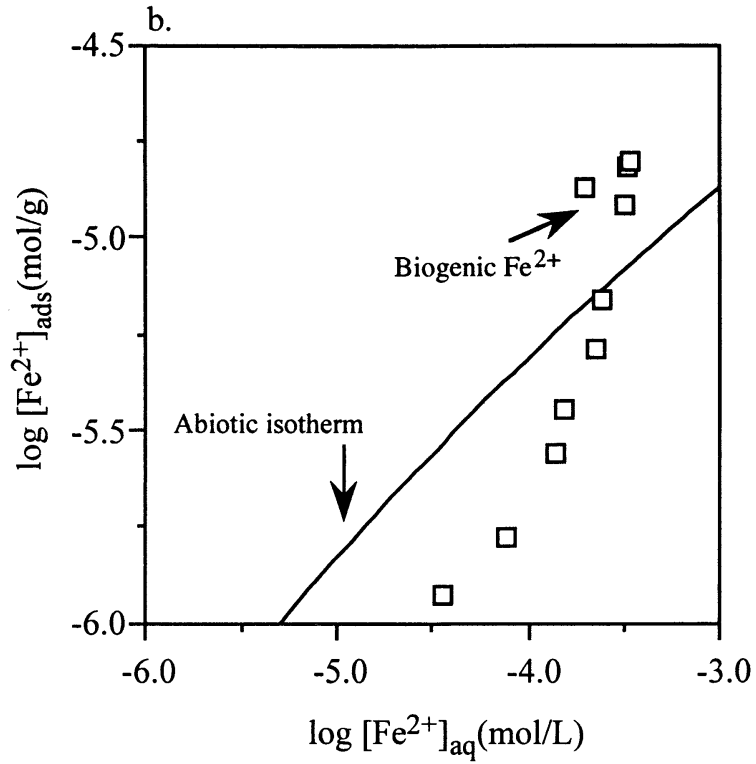

Fig. 13. A comparison of the measured abiotic $\mathrm{Fe}_{(\mathrm{aq})}^{2+}$ adsorption isotherms with the noted Fe(II) solid-liquid distribution in the biotic reduction experiments with BrY. a.) goethite. b.) Milford sediment.

$\mathrm{Co}_{(\mathrm{aq})}^{2+}$ sorption implying independence in adsorption sites. However, $\mathrm{Fe}_{(\mathrm{aq})}^{2+}$ had a strong competitive effect on $\mathrm{Co}_{(\mathrm{aq})}^{2+}$ sorption (one replicate measurement only) at a $\mathrm{Fe}$ :Co ratio $(206: 1)$ and an initial $\mathrm{Co}_{(\mathrm{aq})}^{2+}$ concentration $\left(10^{-5.2} \mathrm{~mol} / \mathrm{L}\right)$ that was similar to the biotic experiments (Fig. 12). Under these specific conditions, $\mathrm{Co}_{(\mathrm{aq})}^{2+}$ sorption was reduced by a factor of nine, indicating that competitive interactions may have been important in our experiments with high surface concentrations of Fe(II). Our data was insufficient to establish whether the apparent competitive effect resulted from mass action or surface modification.

\subsection{Biotic Effects}

The abiotic $\mathrm{Fe}_{(\mathrm{aq})}^{2+}$ titration experiments (Figs. 7, 8) were performed to determine whether the microbial effects could be attributed solely to $\mathrm{Fe}(\mathrm{II})$ generation. Indeed, there were differences between the abiotic and biotic experiments, but generalizing the results was difficult because of experimental $\mathrm{pH}$ variations and differences in sorption of the goethite and the sediment. The addition of microorganisms to goethite/ Co(II)EDTA ${ }^{2-}$ suspensions tended to reduce the overall sorption of both Co(II) and EDTA ${ }^{2-}$ (Fig. 4), possibly because the negatively charged cells adhered to sorbing particle surfaces. Comparable effects were not evident for the Milford sediment (Fig. 5). Another observed difference was that the $\mathrm{K}_{\mathrm{d}}-\mathrm{Co}$ (II) in the abiotic experiment tended to decrease (relative to EDTA ${ }^{4-}$ ) after $\mathrm{Fe}_{(\text {aq) }}^{2+}$ induced displacement from $\mathrm{Co}$ (II)EDTA ${ }^{2-}$ (except at high $\mathrm{pH}$ in Fig. 8a), while it increased in the biotic experiment. We attribute these differences to variations in suspension $\mathrm{pH}$. In the abiotic experiments, a significant decrease was noted in solution $\mathrm{pH}$ (Table 8 and 9) with increased sorption density of $\mathrm{Fe}$ (II) and the appearance of $\mathrm{Fe}_{(\mathrm{aq})}^{2+}$. The proton evolution was consistent with reaction (1). Thus, the build-up of $\mathrm{Fe}_{(\mathrm{aq})}^{2+}$, which destabilized Co(II)EDTA ${ }^{2-}$, was associated with both a decrease in solution $\mathrm{pH}$ and a decrease in sorption affinity of the solid for $\mathrm{Co}^{2+}$, consistent with the $\mathrm{pH}$ trend in Figure 1a. In contrast, the bioreduction increased $\mathrm{pH}$ [reaction (8), Table 4], which, in turn, lead to an increase in sorption affinity of $\mathrm{Co}^{2+}$ [e.g., $\mathrm{K}_{\mathrm{d}}$ - $\mathrm{Co}(\mathrm{II})$ ].

It has been assumed, herein, that sorbed biogenic Fe(II) (e.g., Fig. 3) was chemically equivalent to sorbed $\mathrm{Fe}(\mathrm{II})$ resulting from abiotic spiking with $\mathrm{Fe}_{(\text {aq) }}^{2+}$ (e.g., Fig. 1 or Fig. 2). Clearly, there is no basis to assume that a ferrous iron surface complex is chemically equivalent to biotically generated lattice $\mathrm{Fe}$ (II). Nonetheless, we assumed that the solid-liquid distribution of biogenic $\mathrm{Fe}(\mathrm{II})$ would follow the abiotically determined $\mathrm{Fe}_{(\mathrm{aq})}^{2+}$ sorption isotherm, and that the abiotic experiment was a relevant chemical model of the biotic one. It was difficult in practice to demonstrate this presumed chemical equivalence because of the inability to distinguish $\mathrm{Fe}$ (II) species associated with the solids; and lack of control on the bacterial reduction reaction (e.g., $\mathrm{Fe}(\mathrm{II})_{\text {тот }}$ ) and the final $\mathrm{pH}$, in spite of the buffer. For the limited cases where sufficient data was available for comparison, the results were ambiguous (Fig. 13). The biotic systems seemed to reach higher maximum sorption densities of $\mathrm{Fe}(\mathrm{II})$ for both goethite and the Milford sediment. The $\mathrm{pH}$ issue as noted in the preceding paragraph was crucial here as well. The measured tendency for $\mathrm{pH}$ to decrease with increasing sorption density in the abiotic experiment lead to a reduction in isotherm slope with increasing $\left[\mathrm{Fe}^{2+}\right]_{\mathrm{TOT}}$, while the increase in $\mathrm{pH}$ that accompanied biotic Fe(II) generation lead to a sharply contrasting effect when microorganisms were present (Fig. $13 \mathrm{~b}$, note the $\mathrm{pH}$ for the biotic experiment in Table 6).

Urrutia et al. (1998) found that $S$. alga adsorbed significant quantities of $\mathrm{Fe}_{(\mathrm{aq})}^{2+}$, implying that enhanced $\mathrm{Fe}$ (II) sorption noted here in the biotic experiments could result from binding to cells and cell fragments. Using their data, however, and the organism concentrations in our experiments, we calculated that 

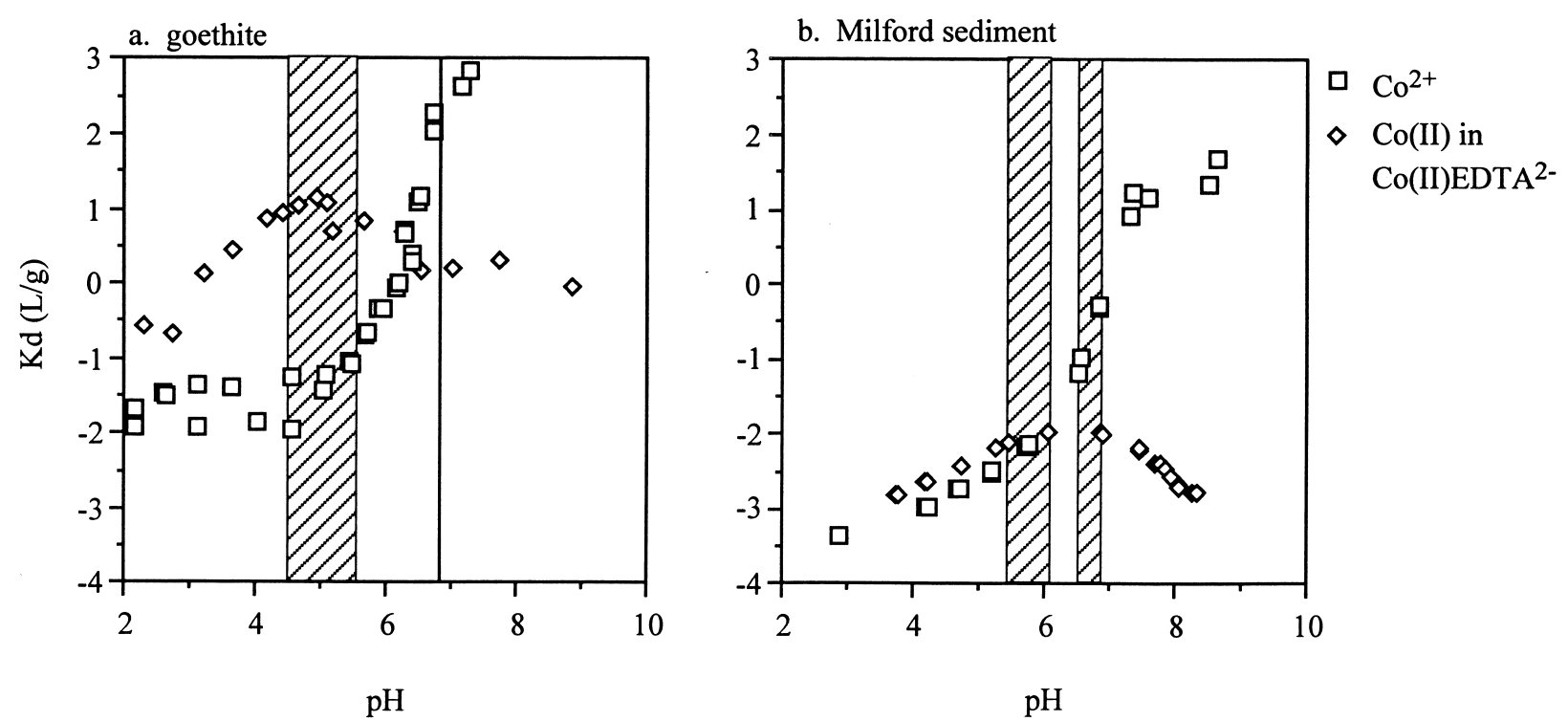

Fig. 14. A comparison of the sorption of $\mathrm{Co}_{(\mathrm{aq})}^{2+}$ and $\mathrm{Co}(\mathrm{II}) \mathrm{EDTA}_{(\mathrm{aq})}^{2-}\left(\right.$ as $\log \mathrm{K}_{\mathrm{d}}$ ) on goethite and Milford sediment. Data for panel a.) was taken from Figures 1a,c. Data for panel b.) was taken from Figures 2a and 2c.

the amount of Fe(II) sorbed to the organisms should be insignificant compared to the mineral solids.

\subsection{Differences Between Goethite and the Subsurface Sediment}

Significant differences were noted in the behavior of Co(II)EDTA ${ }^{2-}$ in the biotic experiments with goethite and the Milford sediment (Figs. 4 and 5). In both experiments there was a tendency for the $\mathrm{K}_{\mathrm{d}}-\mathrm{Co}$ (II) to increase, relative to $\mathrm{EDTA}^{4-}$, as bacterial reduction liberated $\mathrm{Fe}(\mathrm{II})$. However, the relative extent of $\mathrm{K}_{\mathrm{d}}$ increase was far greater in the Milford sediment. This difference resulted from two related factors. First, the Milford sediment was a less effective sorbent of $\mathrm{Fe}(\mathrm{II})$ in both strength and capacity than was goethite. Consequently, $\mathrm{Fe}_{(\mathrm{aq})}^{2+}$ in the microbially-reduced Milford suspensions evolved to higher concentrations (Fig. 3) which facilitated dissociation of Co(II)EDTA ${ }^{2-}$. Secondly, Me(n)EDTA ${ }^{(4-n)-}$ complexes were more weakly sorbed in the Milford sediment than on goethite (Fig. 14). Organic coatings on the oxides or co- or surfaceprecipitated silica may be responsible for the reduced sorptivity of the anionic complexes (Zachara et al., 1995a,b). The differences between $\mathrm{K}_{\mathrm{d}}-\mathrm{Co}(\mathrm{II})$ and $\mathrm{K}_{\mathrm{d}}$-EDTA ${ }^{4-}$ at maximum were approximately 2 orders of magnitude on goethite, but were close to four orders for the Milford sediment (Fig. 14). Thus, the initial Co(II)EDTA ${ }^{2-}$ complex was weakly sorbed by the Milford sediment, and $\mathrm{Co}^{2+}$ displaced from the complex by biogenic $\mathrm{Fe}_{(\mathrm{aq})}^{2+}$ experienced a greater relative enhancement in sorption [e.g., $\left.\mathrm{K}_{\mathrm{d}}-\mathrm{Co}(\mathrm{II})\right]$ than on goethite.

The goethite and Milford sediment were mineralogically different. The Milford sediment contained fine-grained kaolinite in mass concentration comparable to, or exceeding that of goethite. We speculated that the speciation of biogenic Fe(II), would be different from goethite in the Milford sediment, with significant concentrations of $\mathrm{Fe}(\mathrm{II})$ adsorbed by kaolinite and other accessory phases. We expected that these differences in
$\mathrm{Fe}(\mathrm{II})$ speciation would impact $\mathrm{Co}(\mathrm{II}) \mathrm{EDTA}^{2-}$ behavior, but did not observe such effects.

\section{IMPLICATIONS TO SUBSURFACE ENVIRONMENTS}

Weakly-sorbing metal-ligand complexes [e.g., Co(II)EDTA ${ }^{2-}$ ] of intermediate stability (e.g., $\log K>15$ ) may be destabilized in ferrogenic groundwaters. Competition with $\mathrm{Fe}_{(\mathrm{aq})}^{2+}$ displaces the metal ion from the complex. The degree of displacement is controlled by the concentration ratio of $\mathrm{Fe}_{(\mathrm{aq})}^{2+}$ to the metal in the complex [e.g., $\mathrm{Co}(\mathrm{II})$ in this case], their respective stability constants for the ligand, and the adsorption strength of the dissociation products for mineral surfaces. The displacement reactions were rapid, occurring within the time frame of hours to days. Sorbed Fe(II) did not appear to participate in the dissociation reaction. Complicated geochemical behavior can result for contaminant metals such as $\mathrm{Co}^{2+}$ that are complexbound because of the multi-species distribution of products. Different chemical species of the metal [e.g., Co(II)EDTA ${ }^{2-}$ and $\mathrm{Co}^{2+}$ ] may exhibit vastly different retardation behavior. In ferrogenic groundwaters promoted by dissimilatory bacterial iron reduction, the metal-ligand complexes may show progressive down-gradient dissociation as a result of the changing $\mathrm{Me} / \mathrm{Fe}$ ratio promoted by chemical reaction and advection.

In the circumneutral $\mathrm{pH}$ range with $\mathrm{Fe}$ (III) and $\mathrm{Al}(\mathrm{III})$ oxide containing sediments, small differences in $\mathrm{pH}$ may be important in controlling whether the displaced metal (e.g., $\mathrm{Co}^{2+}$ ) or the ligand (as $\mathrm{Fe}(\mathrm{II}) \mathrm{L}^{2-}$ ) is more mobile, because their adsorption edges tend to cross in that $\mathrm{pH}$ region. In the biotic experiments performed here, the evolution of $\mathrm{Fe}_{(\mathrm{aq})}^{2+}$ invariably led to an increase in the $\mathrm{K}_{\mathrm{d}}$ of the displaced metal relative to the complexing ligand, which, in groundwater, would reduce the mobility of the originally complexed metal. This resulted from the net increase in system $\mathrm{pH}$ that accompanied bacterial $\mathrm{Fe}(\mathrm{III})$ oxide reduction. Ferrogenic conditions would, for example, lead to the immobilization of ${ }^{60} \mathrm{Co}$ or ${ }^{239 / 240} \mathrm{Pu}$, which 
are reportedly mobilized by complexation with EDTA ${ }^{4-}$ (Means et al., 1978; Means and Alexander, 1981; Olsen et al., 1986). The magnitude of adsorption of the displaced metal, however, would be less than in comparable oxidized sediments due to sorptive competition with surface and aqueous $\mathrm{Fe}^{2+}$. Sorbing mineral surfaces in circumneutral ferrogenic groundwaters are likely to be near saturation with Fe(II), as shown here and by Heron et al., (1994). Such saturation may or may not influence the sorptive behavior of incoming contaminant anions or cations. Surprisingly the bacterial reduction of a sizable portion, i.e., $20 \%$, of the $\mathrm{Fe}(\mathrm{III})$ oxide fraction of a subsurface material need not influence the intrinsic sorptivity of the sediment as shown for the sorption of Co(II)EDTA ${ }^{2-}$ by the bioreduced [washed free of sorbed Fe(II)] Milford sediment.

Acknowledgments-This research was supported by the Natural and Accelerated Bioremediation Research Program (NABIR), Office of Biological and Environmental Research (OBER), and U.S. Department of Energy (DOE). Geological materials used in this paper were taken from the NABIR subsurface sediment collection. Critical reviews of this manuscript by Dr. D. C. Girvin of Pacific Northwest National Laboratory and two anonymous reviewers are appreciated.

\section{REFERENCES}

Abrechtsen H.-J. and Christensen T. H. (1994) Evidence for microbial iron reduction in a landfill leachate-polluted aquifer (Vejen, Denmark). Appl. Environ. Microbiol. 60(11), 3920-3925.

Arnold R. G., DeChristina T. J., and Hoffman M. R. (1988) Reductive dissolution of Fe(III) oxides by Pseudomonas sp. 200. Biotechnol. Bioengineer. 32, 1081-1096.

Bedsworth W. W. and Sedlak D. L. (1999) Sources and environmental fate of strongly complexed nickel in estuarine waters: The role of ethylenediaminetetraacetate. Environ. Sci. Technol. 33, 926-931.

Bowers A. R. and Huang C. P. (1986) Adsorption characteristics of metal-EDTA complexes on hydrous oxides. J. Coll. Interf. Sci. 110, $575-590$.

Brooks S. C. and Jardine P. M. (1996) Reactive transport of EDTAcomplexed cobalt in the presence of ferrihydrite. Geochim. Cosmochim. Acta 60(11), 1899-1908.

Caccavo F., Blakemore R. P., and Lovley D. R. (1992) A hydrogenoxidizing, $\mathrm{Fe}(\mathrm{III})$-reducing microorganism from the Great Bay Estuary, New Hampshire. Appl. Environ. Microbiol. 58(10), 32113216.

Chapelle F. H. (1993) Ground-Water Microbiology and Geochemistry. John Wiley \& Sons, Inc.

Davis J. A. and Kent D. B. (1990) Surface complexation modeling in aqueous geochemistry. In Mineral-Water Interface Geochemistry (ed. A. White and M. Hochella); Rev. Mineral. 23, 177-260.

Evanko C. R. and Dzombak D. A. (1998) Influence of structural features on sorption of NOM-analogue organic acids to goethite. Environ. Sci. Technol. 32, 2846-2855.

Fredrickson J. K., Zachara J. M., Kennedy D. W., Dong H., Onstott T. C., Hinman N. W., and Li S.-M. (1998) Biogenic iron mineralization accompanying the dissimilatory reduction of hydrous ferric oxide by a groundwater bacterium. Geochim. Cosmochim. Acta (in press).

Girvin D. C., Gassman P. L., and Bolton H. J. (1993) Adsorption of aqueous cobalt ethylenediaminetetraacetate by $\delta-\mathrm{Al}_{2} \mathrm{O}_{3}$. Soil Sci. Soc. Am. J. 85, 1-11.

Girvin D. C., Gassman P. L., and Bolton H. J. (1996) Adsorption of nitrilotriacetate (NTA), Co, and CoNTA by gibbsite. Clays Clay Miner. 44, 757-768.

Hayes K. F. and Katz L. E. (1996) Application of X-ray absorption spectroscopy for surface complexation modeling of metal ion sorption. In Physics and Chemistry of Mineral Surfaces (ed. P. V. Brady), pp. 147-223. CRC Press, Boca Raton.

Heron G. and Christensen T. H. (1995) Impact of sediment-bound iron on redox buffering in a landfill leachate polluted aquifer (Vejen, Demark). Environ. Sci. Technol. 29, 187-192.

Heron G., Crouzet C., Boug A. C. M., and Christensen T. H. (1994) Speciation of $\mathrm{Fe}(\mathrm{II})$ and $\mathrm{Fe}$ (III) in contaminated aquifer sediments using chemical extraction techniques. Environ. Sci. Technol. 28, $1698-1705$.

Killey D. R. W., McHugh J. O., Champ D. R., Cooper E. L., and Young J. L. (1984) Subsurface cobalt-60 migration from a low-level waste disposal site. Environ. Sci. Technol. 18, 148-157.

Lovley D. R. (1993) Dissimilatory metal reduction. Ann. Rev. Microbiol. 47, 263-290.

Lovley D. R. and Chapelle F. H. (1995) Deep subsurface microbial processes. Rev. Geophys. 33, 365-381.

Lovley D. R., Chapelle F. H., and Phillips E. J. P. (1990) Fe(III)reducing bacteria in deeply buried sediments of the Atlantic Coastal Plain. Geology 16, 954-957.

Lovley D. R., Phillips E. J. P., Gorby Y. A., and Landa E. R. (1991) Microbial reduction of uranium. Nature 350, 413-416.

Lyngkilde J. and Christensen T. H. (1992a) Fate of organic contaminants in the redox zones of a landfill leachate pollution plume (Vejen, Denmark). J. Contam. Hydrol. 10, 291.

Lyngkilde J. and Christensen T. J. (1992b) Redox zones of a landfill leachate pollution plume (Vejen, Denmark). J. Contam. Hydrol. 10, 273.

Means J. L. and Alexander C. A. (1981) The environmental biogeochemistry of chelating agents and recommendations for the disposal of chelated radioactive wastes. Nucl. Chem. Waste Manage. 2, 183196.

Means J. L., Crerar D. A., and Duguid J. O. (1978) Migration of radionuclide wastes: Radionuclide mobilization by complexing agents. Sci. 200, 1477-1486.

Myers C. R. and Nealson K. H. (1988) Bacterial manganese reduction and growth with manganese oxide as the sole electron acceptor. Sci. 240, 1319-1321.

Nowack B. and Sigg L. (1996a) Adsorption of EDTA and metal-EDTA complexes onto goethite. J. Coll. Interf. Sci. 177, 106-121.

Nowack B., Lutzenkirchen J., Behra P., and Sigg L. (1996b) Modeling the adsorption of metal-EDTA complexes onto oxides. Environ. Sci. Technol. 30, 2397-2405.

Olsen C. R., Lowry P. D., Lee S. Y., Larsen I. L., and Cutshall N. H. (1986) Geochemical and environmental processes affecting radionuclide migration from a formerly used seepage trench. Geochim. Cosmochim. Acta 50, 593-607.

Phillips E. J. P., Lovley D. R., and Roden E. E. (1993) Composition of non-microbially reducible $\mathrm{Fe}(\mathrm{III})$ in aquatic sediments. Appl. Environ. Microbiol. 59, 2727-2729.

Roden E. E. and Zachara J. M. (1996) Microbial reduction of crystalline Fe(III) oxides: Influence of oxide surface area and potential for cell growth. Environ. Sci. Technol. 30, 1618-1628.

Rosselló-Mora R. A., Caccavo F. J., Osterlehner K., Springer N., Spring S., Schler D., Ludwig W., Amann R., Vanncanneyt M., and Schleifer K. H. (1994) Isolation and taxonomic characterization of a halotolerant, facultatively iron-reducing bacterium. System. Appl. Microbiol. 17, 569-573.

Schwertmann U., Cambier P., and Murad E. (1985) Properties of goethite of varying crystallinity. Clays Clay Miner. 33, 369-378.

Sposito G. (1984) The Chemistry of Soils. Oxford University Press, New York.

Szecsody J. E., Zachara J. M., and Bruckhart P. L. (1994) Adsorptiondissolution reactions affecting the distribution and stability of Co(II)EDTA in Fe oxide-coated sand. Environ. Sci. Technol. 28, $1706-1716$.

Szecsody J. E., Zachara J. M., Chilakapati A., Jardine P. M., and Ferrency A. S. (1998a) Importance of flow and particle-scale heterogeneity on Co ${ }^{\mathrm{II} / I I I}$ EDTA reactive transport. J. of Hydrol. 209, $112-136$.

Szecsody J. E., Chilakapati A., Zachara J. M., and Garvin A. L. (1998b) Influence of iron oxide inclusion shape on $\mathrm{Co}^{\mathrm{II} / I I}$ EDTA reactive transport through spatially heterogeneous sediment. Water Resour. Res. 34(10), 2501-2514.

Urrutia M. M., Roden E. E., Fredrickson J. K., and Zachara J. M. (1998) Microbial and surface chemistry controls on reduction of 
synthetic Fe(III)-oxide minerals by the dissimilatory iron-reducing bacterium Shewanella alga. Geomicrobio. 15, 269-291.

Urrutia M. M., Roden E. E., and Zachara J. M. (1999) Influence of aqueous and solid-phase $\mathrm{Fe}(\mathrm{II})$ complexants on microbial reduction of crystalline Fe(III) oxides. Environ. Sci. Technol. 33, 4022-4028.

Xue H., Sigg L., and Kari F. G. (1995) Speciation of EDTA in natural waters: Exchange kinetics of Fe-EDTA in river water. Environ. Sci. Technol. 29, 59-68.

Zachara J. M., Resch C. T., and Smith S. C. (1994) Influence of humic substances on $\mathrm{Co}^{2+}$ sorption by a subsurface mineral separate and its mineralogic components. Geochim. Cosmochim. Acta 58(2), 553-566.

Zachara J. M., Smith S. C., Resch C. T., and Cowan C. E. (1992) Cadmium sorption to soil separates containing layer silicates and iron and aluminum oxides. Soil Sci. Soc. Am. J. 56, 1074-1084.
Zachara J. M., Gassman P. L., Smith S. C., and Taylor D. (1995a) Oxidation and adsorption of Co(II) EDTA ${ }^{2-}$ complexes in a subsurface materials with iron and manganese oxides. Geochim. Cosmochim. Acta 59(21), 4449-4463.

Zachara J. M., Smith S. C., and Kuzel L. S. (1995b) Adsorption and dissociation of Co-EDTA complexes in iron oxide-containing subsurface sands. Geochim. Cosmochim. Acta 59, 4825-4844.

Zachara J. M., Fredrickson J. K., Li S.-M., Smith S. C., and Gassman P. L. (1998) Bacterial reduction of crystalline Fe(III) oxides in single phase suspensions and subsurface materials. Am. Mineral. 83, 14261443.

Zachara J. M., Smith S. C., and Fredrickson, J. K. (1999) Reductive solubilization of $\mathrm{Co}^{2+}$ from $\mathrm{FeCoOOH}$ by a dissimilatory iron reducing bacterium. Geochim. Cosmochim. Acta (Submitted). 